Int. J. Dev. Biol. 48: 1045-1058 (2004)

doi: $10.1387 / \mathrm{ijdb} .041895 \mathrm{~ms}$

\title{
Development and pathology of the hyaloid, choroidal and retinal vasculature
}

\author{
MAGALI SAINT-GENIEZ and PATRICIA A. D'AMORE* \\ Schepens Eye Research Institute, Boston, MA, USA and Departments of Ophthalmology and Pathology, Harvard Medical School, \\ Boston, MA, USA
}

\begin{abstract}
During embryogenesis, the development and differentiation of the eye requires the concomitant formation of the neural/glial elements along with a dense vascular network. The adult neural retina is supported by two distinct vascular systems, the proper retinal vessels and the choroidal vessels. The two beds differ not only in their pattern of embryonic differentiation, but also in their function in the adult organism. The retinal vasculature has barrier properties similar to those observed in the brain, whereas the choroidal vessels display a highly fenestrated phenotype. The hyaloid vasculature is a transient embryonic vascular bed which is complete at birth in mammals and regresses contemporaneously with the formation of the retinal vasculature. The dependence of the retina on its blood supply makes it highly vulnerable to any vascular changes and indeed ocular diseases, such as proliferative retinopathy, age-related macular degeneration and the hyperplastic primary vitreous, which are associated with abnormalities of the different vascular beds of the eye. A number of factors have been implicated in developmental and pathological changes in vessel formation and regression, including fibroblast growth factors, platelet-derived endothelial growth factor and vascular endothelial growth factor, among others. The purpose of this review is to describe and discuss new insights into the mechanisms and molecular cues involved in the development of the normal and pathological vascular systems of the eye. The characterization of the molecules and cell-cell interactions involved in the formation, stabilization and regression of new vessels has led to the identification of potential control points for therapeutic intervention.
\end{abstract}

KEY WORDS: angiogenesis, vascularization, retinopathy of prematurity, diabetic retinopathy

\section{Cell and molecular mechanisms of vascularization}

Blood vessels are among the first organs to develop and are derived entirely from the mesoderm (Coffin, J.D. and Poole, T.J., 1988; Pardanaud, L. et al., 1989). Blood vessels, in general, are composed of distinct cell layers. The intima, the innermost layer, is made up of a single layer of endothelial cells (EC). The media is composed of several layers of mural cells, smooth muscle cells in large vessels and a non-overlapping single layer of pericytes in microvessels. The outermost layer of large vessels, known as the adventitia, consists of loose connective tissue containing smaller blood vessels and nerves.

Vascular development occurs via two processes termed vasculogenesis and angiogenesis. Vasculogenesis, blood vessel assembly during embryogenesis, begins with clustering of primitive vascular cells or hemangioblasts (Doetschman, T.A. et al., 1987), into tube-like endothelial structures, which define the pattern of the vasculature (Noden, D.M., 1989). Tissues that are vascularized by this process are generally of endodermal origin and include lung and pancreas, as well as the heart tube and dorsal aorta (Pardanaud, L. et al., 1989). In angiogenesis, new vessels arise by sprouting from pre-existing vessels, usually venules (Fig. 1). Tissues of ectodermal and mesodermal derivation such as the kidney, brain and retina are thought to be vascularized primarily via angiogenesis.

Abbreviations used in this paper: ang, angiopoietins; ARMD, age-related macular degeneration; CNV, choroidal neovascularization; EC, endothelial cells; EPC, endothelial precursor cells; FGF, fibroblast growth factor; GA, geographic atrophy; HIF-1, hypoxia-inducuble factor- 1 ; HVS, hyaloid vascular system; PDGF, platelet-derived growth factor; PDR, proliferative diabetic retinopathy; PEDF, pigment epithelium-derived factor; PM, pupillary membrane; pVHL, von Hippel-Lindau tumor suppressor gene product; ROP, retinopathy of prematurity; RPE, retinal pigment epithelium; TGF- $\beta$, transforming growth factor beta; TVL, tunica vasculosa lentis; VEGF, vascular endothelial growth factor; VEGFR1, VEGF receptor 1; VEGFR2, VEGF receptor 2; VPF, vascular permeability factor. 


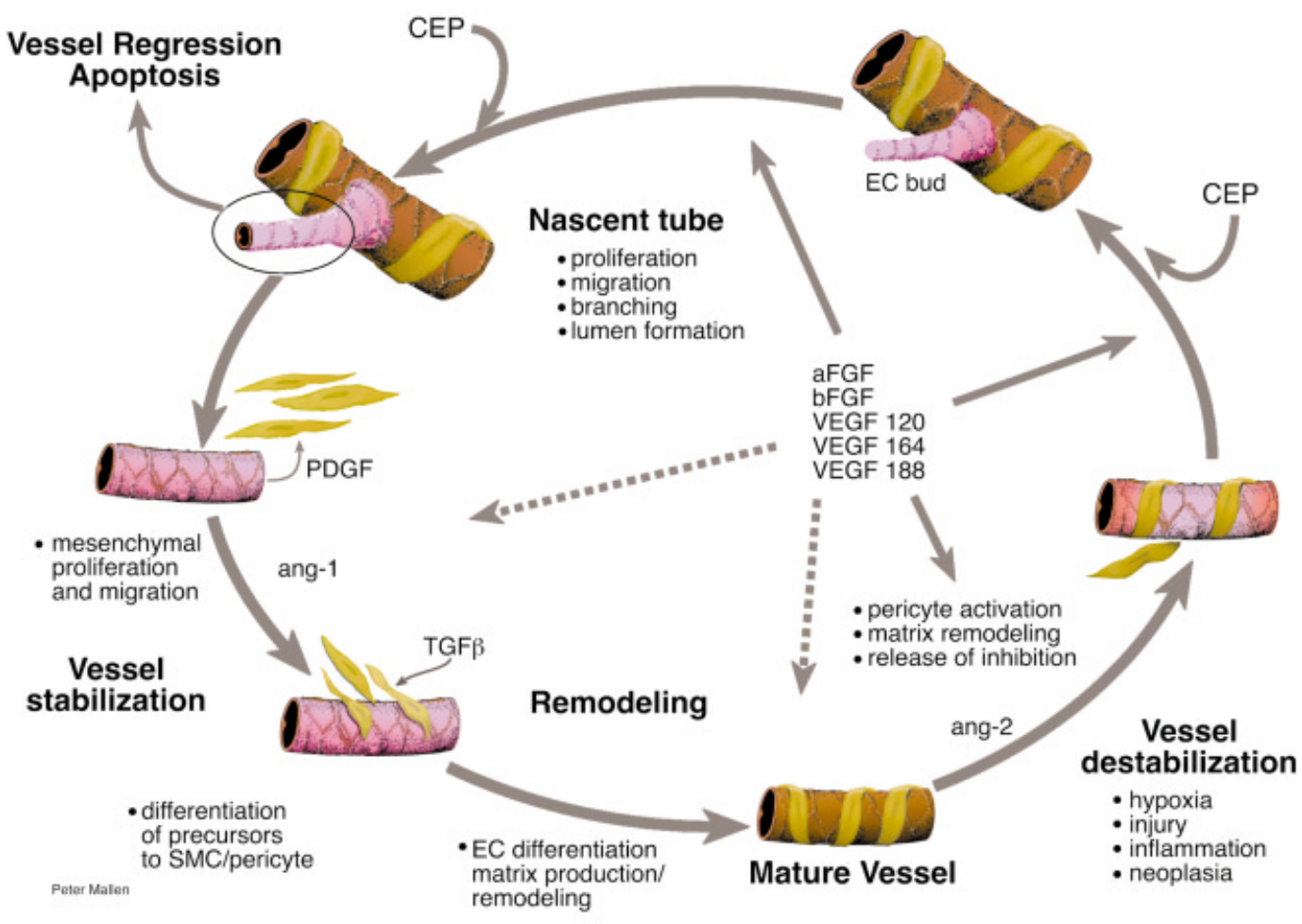

Fig. 1. Assembly of a stable vessel. Local increases in angiogenic growth factors such as vascular endothelial growth factor (VEGF) and fibroblast growth factor (FGF) during new vessel formation destabilize a portion of pre-existing vessel (usually a venule). This destabilization is associated with increased angiopoietin (ang)-2 expression and with pericyte activation, matrix remodeling, and induction of pericyte and endothelial cell (EC) migration and proliferation. Newly formed vessels are dependent on exogenous factors for their survival until they have been remodeled to mature structures. Remodeling involves EC recruitment of pericytes/smooth muscle cell (SMC) precursors via endothelial secretion of platelet-derived growth factor (PDGF). Once the mural cell precursormakes contact with the nascent vessel,

transforming growth factor (TGF)- $\beta$ is activated, which in turn suppresses their proliferation and migration and induces their differentiation into smooth muscle cells/pericytes. In addition to TGF- $\beta$, ang-1 produced by the pericytes is also involved in the stabilization and maintenance of the vessels. a- $F G F$, acidic fibroblast growth factor (or FGF-1); b-FGF, basic fibroblast growth factor (or FGF-2); CEP, circulating endothelial precursor.

In addition, angiogenesis appears to be the predominant means of neovascularization during events such as wound healing and during pathologies such as proliferative diabetic retinopathy.

Whether vessels form by angiogenesis or vasculogenesis, the primitive vessels are subsequently remodeled. Remodeling is a poorly understood event that involves growth of new vessels and the regression of others, as well as changes in lumen diameter and vessel wall thickness, to suit the local tissue needs. Embryonic data suggest that the EC may govern the subsequent development of vessel layers. As the endothelial tubes invade organ primordia, they become surrounded by locally derived mesenchymal cells (i.e. precursors of mural cells, adventitial fibroblasts) forming the medial coat (Nakamura, H., 1988). Tissue culture studies using cocultures of $E C$ and mesenchymal have demonstrated that $E C$ secrete platelet derived growth factor (PDGF) BB that acts to stimulate the proliferation of the mesenchymal cells and their chemotaxis toward the EC (Hirschi, K. et al., 1998; Hirschi, K.K. et al., 1999). These tissue culture data have been validated in vivo and a role of PDGFBB in vessel remodeling in vivo has been established by analysis of the phenotype of mice deficient for PDGF B or PDGF receptor $\beta$ (Lindahl, P. et al., 1997; Hellstrom, M. et al., 1999). Both lines of mice had reduced numbers of pericytes and smooth muscle cells, presumably due to both reduced migration and proliferation. Analysis of the microvasculature has revealed that $\mathrm{EC}$ of newly forming vessels are not able to attract pericyte progenitors that express PDGF receptor $\beta$ (Lindahl, P. et al., 1997). Mice deficient in PDGF B have a paucity of pericytes in the brain, heart, lung and adipose, which leads to the development of microaneurysms.
A role for the tie2-angiopoietin system in vessel assembly is also indicated by the phenotypes of knock-out mice (Dumont, D.J. et al., 1994; Suri, C. et al., 1996). Mice deficient in tie2 or angiopoietin1 are embryonic lethal and display significant defects in vessel assembly. On the other hand, angiopoietin2 is not required for embryonic angiogenesis, but appears to be necessary for postnatal vascular remodeling (Gale, N.W. et al., 2002). Use of gene targeting in a murine model of retinal vascularization has shown that angiopoietin2 is essential for sprouting and regression, constituent events of the remodeling process (Maisonpierre, P.C. et al., 1997; Gale, N.W. et al., 2002).

Observations over the past several years have indicated a role for yet another mechanism in vessel formation and growth. The existence of circulating endothelial precursor cells (EPC) is well established (for review see (Rafii, S. and Lyden, D., 2003). As for other examples of post-natal angiogenesis (Rafii, S. etal., 2002), bone-marrow derived stem cells have been shown to contribute to retinal angiogenesis (Grant, M.B. et al., 2002; Otani, A. et al., 2002). The extent to which circulating endothelial cell precursors contribute to neovascularization in animal models has not been determined and if the phenomenon occurs in humans is entirely unknown.

Although there are fundamental differences between angiogenesis and vasculogenesis, these two processes also share a number of regulatory features. The recent identification of a number of vesselspecific receptors and ligands combined with the ability to genetically manipulate the mouse genome has begun to provide insight into the molecular mechanisms that regulate vessel assembly. Specific molecules involved in vascular development include vascular 
endothelial growth factor (VEGF) and its receptors, VEGF receptor 1 (VEGFR1, flt-1), VEGF receptor 2 (VEGFR2, flk-1) and neuropilin1; PDGF $A$ and $B$ and their receptors $\alpha$ and $\beta$; angiopoietins (ang) 1 and 2 and their receptor tie2; and, transforming growth factor beta (TGF- $\beta$ ) and the TGF- $\beta$ receptors 1 and 2 , to name just a few (for review see (Darland, D.C. and D'Amore, P.A., 2001).

One factor that has received a great deal of attention to date is VEGF. VEGF-A, the prototypic member of a family of secreted, homodimeric glycoproteins, is an endothelial specific mitogen and stimulates angiogenesis in vivo (Leung, D.W. et al., 1989). VEGF also induces vascular permeability, with an effect 10,000 times more potent than that of the vasoactive substance histamine. VEGF was originally discovered based on this property and named vascular permeability factor (VPF) (Senger, D.R. et al., 1983). Murine VEGF$A$ includes three biochemically distinct protein isoforms generated through alternative splicing of a single gene (Fig. 2) (Tischer, E. et al., 1991; Shima, D.T. etal., 1996). These different gene products exhibit tissue-specific expression during embryogenesis (Ng, Y.-S. et al., 2001) and in the adult organism (Bacic, M. et al., 1995; Ng, Y.-S. et al., 2001). The biochemical investigations of VEGF isoforms have focused on the distinct heparin-binding properties of the different proteins. The affinity of each VEGF isoform for heparin correlates with that isoform's level of interaction with cell surface and extracellular matrix molecules upon secretion from the cell (Houck, K.A. et al., 1992). VEGF 120 does not bind heparin and is therefore freely soluble. VEGF164 binds heparin with moderate affinity and protein released from cells is found bound to the matrix and soluble in the media. VEGF 188 has a strong affinity for heparin and is nearly completely sequestered to the cell surface and extracellular matrix after its secretion.

Studies of the mitogenic effects of the VEGF isoforms indicate that they differ in their biological potency with VEGF164 100-fold more mitogenic than VEGF120 (Keyt, B.A. et al., 1996). Identification of a receptor, termed neuropilin-1, that binds VEGF 164 but not VEGF120 (Soker, S. et al., 1996) further supports the hypothesis that the various VEGF isoforms are not functionally equivalent. Functional evidence to support distinct roles for the isoforms is now emerging. Mice that express only VEGF120 live to term but die within 2 weeks of birth as a result of a variety of vascular defects (Carmeliet, P. et al., 1996). We have also found vascular defects in VEGF188/188 mice including abnormal vascular remodeling in the lung and retina (Galambos, C. et al., 2002; Stalmans, I. et al., 2002). Taken together, these finding prove that the VEGF isoforms are not functionally equivalent and that they serve specific functions during vascular development.

\section{Embryonic development of the ocular vasculature}

The development of the eye, as other organs, depends on the concomitant formation of a complex vascular system to provide nutrients and oxygen for the ocular tissues at the time of their

\section{B} Boston, MA, USA). active differentiation. This intense angiogenic process is followed by the eradication of part of the vessels, a process called pruning, in order to adapt the blood flow to the needs and physiologic characteristics of the differentiated tissues. The mature retina is a highly metabolic neural tissue with the highest oxygen consumption per unit weight of any human tissue. In most mammals, the adult retina is vascularized by two independent circulatory systems: the choroid and the retinal vessels. During the initial development of the eye, the oxygenation of the retina is ensured by the choroidal vessels and the hyaloid system. The vascularization of the retina itself occurs only during the late gestation and is restricted to the inner part of the retina, with the outer retina completely avascular to ensure visual function. The hyaloid vessel system is a dense, but transient, intraocular circulatory system that undergoes progressive and nearly complete regression during the latest stage of ocular development as the lens, the vitreous and the retina mature.

\section{The choroidal vascular system}

During early development, the ocular vascular system emerges from the mesoderm surrounding the newly formed optic cup. At the $5 \mathrm{~mm}$ stage in humans, the primitive dorsal and ventral ophthalmic arteries branch from the internal carotid artery. The hyaloid artery arises from the primitive dorsal ophthalmic artery, passing through the embryonic fissure into the optic cup. The uveal vascular system develops as early as the invagination of the optic vesicle $(4-5 \mathrm{~mm}$ stage), with the formation of a large plexus of primitive vessels originating from the neural tube vascular system and extending around the outer layer of the optic cup. The initial vascular layer
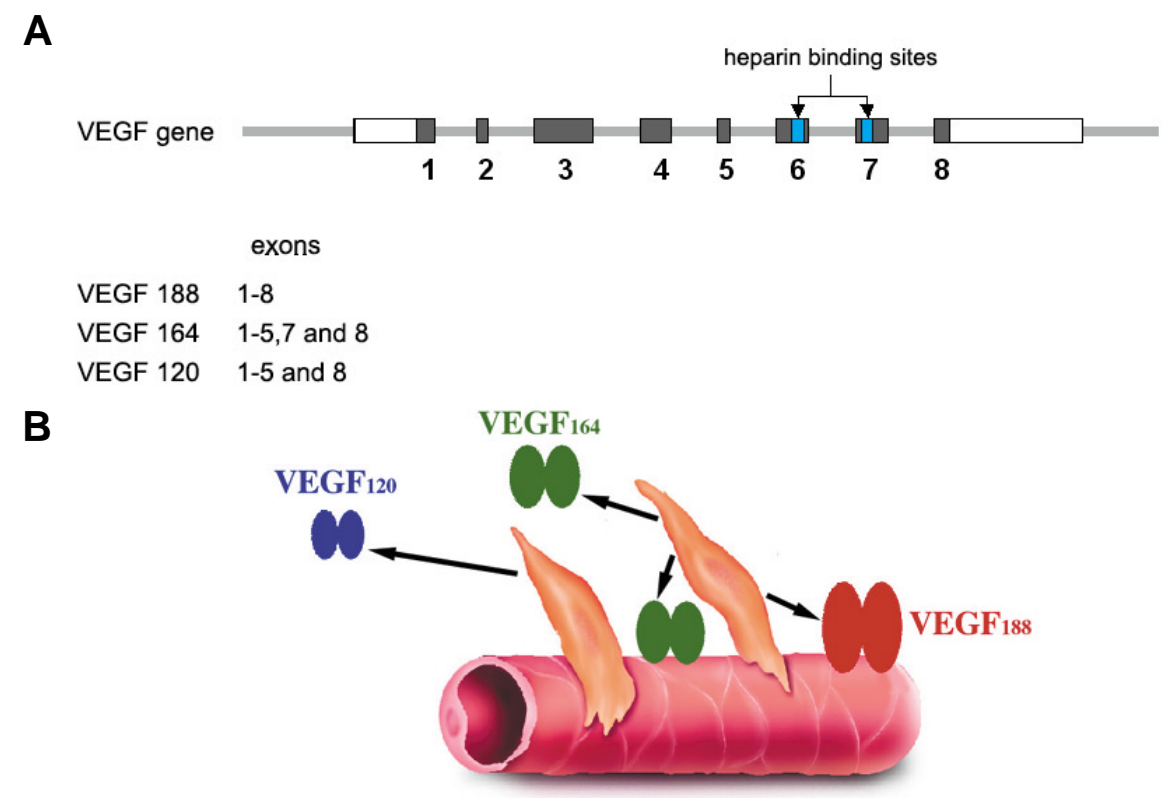

Fig. 2. Structure and extracellular localization of the VEGF isoforms. (A) In mice, as in humans, the different VEGF isoforms are generated by alternative splicing of one single gene. The isoforms differ by the presence or absence of heparin binding domains encoded by exons six and seven. (B) The ability of the VEGF isoforms to diffuse into the extracellular space depends on the presence of heparin binding sites. VEGF 120, which does not contain any heparin binding domains, is freely diffusible, whereas VEGF188 remains bound to the surface and/or extracellular matrix of the VEGF-producing cell (Modification of original figure produced by Medical Graphics, 
expands and increases in density, following the spreading pigmentation in the retinal epithelium from the posterior pole to the $\mathrm{rim}$ of the optic cup. At the $13 \mathrm{~mm}$ stage, choroidal capillaries completely encircle the optic cup but remain separated from the neural retina by the basement membrane of the retinal pigment epithelium (RPE). At the anterior rim of the cup, the choroidal plexus anastomoses and forms a circular vessel, the annular vessel. During the second and third months of gestation, this primitive plexus is organized into a complex network. The choroidal vessels connect to posterior ciliary arteries, the vortex veins that drain the plexus develop and the definitive choriocapillaris layer appears.

Whereas the choroidal endothelial cells originate from the paraocular mesenchyme, all other cells of the choroid, such as stromal cells, melanocytes and pericytes, are derived from cranial neural crest (Torczynski, E., 1982; Etchevers, H.C. et al., 2001). The neural crest cells migrate around the optic vesicle during the closure of the neural tube. These undifferentiated mesenchymal cells are the source of the melanocytes and stroma of the choroid. Pigmentation is a late process in the differentiation of the choroid, as melanin appears between 6 and 7 months and is complete at birth.

Although the molecular mechanisms that govern the formation of the choroid are largely unstudied, the development of the choroidal vasculature appears to depend on the presence of differentiated RPE and their production of inductive signals. The expression of fibroblast growth factor (FGF)-9 under the control of a tyrosine-related protein 2 promoter has been shown to convert most of the RPE into neural retina and to inhibit the formation of the choroid (Zhao, S. and Overbeek, P.A., 2001). Interestingly, it has been observed in human patients with colombas that failure of RPE differentiation leads to defective development of the choroid and sclera (Torczynski, E., 1982). In vitro, RPE cells are able to stimulate tube formation by choroidal cells, an effect that is inhibited by the administration of bFGF and VEGF neutralizing antibodies (Sakamoto, T. et al., 1995). In a mouse model in which a dominant negative FGFR1 is over-expressed in the RPE, choroidal vessels fail to completely develop and remain immature (Rousseau, B. et al., 2003), implicating bFGF in choroidal development. Recently, VEGF and its receptor VEGFR2 have been shown to be highly expressed by the RPE and the underlying mesenchyme, respectively, at the time of the choriocapillaris formation both in humans (Gogat, K. et al., 2004) and rodents (Yi, X. et al., 1998; Zhao, S. and Overbeek, P.A., 2001). Together these findings suggest that RPE expression of angiogenic factors such as VEGF and bFGF may be involved in the development and the differentiation of the choroidal vasculature.

\section{The hyaloid vascular system}

The process of intraocular vascularization begins with the entry of the hyaloid artery into the optic cup through the fetal fissure. Rapidly, the hyaloid artery extends through the primitive vitreous, reaching the posterior pole of the forming lens at the $7 \mathrm{~mm}$ stage. Intense branching of the main vessels over the lens surface forms a dense capillary network, called the tunica vasculosa lentis (TVL), at the $8-9 \mathrm{~mm}$ stage. The wide-meshed capillary network of the TVL anastomoses with the annular vessel at the anterior border of the cup and connects to the choroidal vasculature. The hyaloid system is characterized by the absence of veins; all hyaloid vessels are arteries and the venous drain is accomplished by the choroidal veins. As the lens develops, the TVL expands to reach the anterior part of the lens and forms the pupillary membrane (PM). The development of the hyaloid vascular system (HVS) is complete at $40-60 \mathrm{~mm}$ stage and provides all nutrients to the intraocular components of the developing eye. It is at this stage, which coincides with the development of the retinal vasculature, that the first evidence of hyaloid vessel regression can be detected (Zhu, W.H. et al., 2000).

The precise events and factors involved in the formation and the subsequent regression of the HVS remain poorly defined. Expression studies have shown that VEGF is expressed in the lens in proximity to the forming TVL and PM (Mitchell, C.A. et al., 1998; Shui, Y.B. et al., 2003; Gogat, K. et al., 2004), suggesting that VEGF may be one of the factors that triggers the growth of these two vessel networks. VEGF has been suggested to increase vascular permeability, at least in part by inducing a fenestrated endothelial phenotype (Roberts, W.G. and Palade, G.E., 1995; Bottinger, E. etal., 1997). Thus, the localization of VEGF expression in the vicinity of the TVL and the PM could explain the presence of fenestrations only on the side of the capillaries facing the lens (Sellheyer, K. and Spitznas, M., 1987). Finally, a role for VEGF in the formation of the HVS is also supported by the observation that overexpression of VEGF in the developing lens results in endothelial cell hyperplasia, leading to the formation of a disorganized and persistent intravitreal vascular network (Ash, J.D. and Overbeek, P.A., 2000).

\section{The retinal vasculature}

The molecular and cellular mechanisms involved in the retinal vascularization have been the subject of extensive studies. These have led to major breakthroughs in understanding normal and pathological vascularization processes including the interrelationships among metabolism, hypoxia and vascular outgrowth. In many mammals, the retina remains avascular as its thinness permits an efficient diffusion of oxygen from the choroid. Thus, the formation of the retinal vasculature is associated with the thickening of the retina (Dreher, Z. et al., 1992). Retinal blood vessels are organized in two planar layers that are restricted to the inner layers of the retina. As in the central nervous system, the retinal vascular network is characterized also by its blood-barrier status. This specialization of the endothelial cells is apparently induced by interaction with other cells that participate in retinal vascularization including the Müller cells (Tout, S. et al., 1993) and the astrocytes (Janzer, R.C. and Raff, M.C., 1987). In human retina, the primitive vessels emerge from the optic disc at the base of the hyaloid artery early in the fourth month. During the next four months, the initial network extends and spreads to the periphery of the retina. The formation and maturation of the retinal vascular network is completed only after birth.

The development of the retinal vasculature is frequently used as a model for the mechanisms involved in embryonic vascular development, particularly for the processes of vascular remodeling and maturation. In the 1950's, based on his observations on the growth and organization of the retinal vessels, Michaelson suggested the existence of a "vasoformative factor" whose production would be induced by the local metabolic needs. This factor would be involved not only in the development of the normal retinal vasculature but also in the pathologic neovascularization of the retina (Michaelson, I.C. et al., 1954). The description of this 
factor that would later be named VEGF was the starting-point of numerous studies that lead to our current understanding of the processes and molecules involved in retinal vascularization. Many investigators have described the retinal vascularization as a twostep process, involving the initial formation of the primary internal vascular network by vasculogenesis, followed by an angiogenic phase leading to the deep secondary network (Flower, R.W. et al., 1985) (Chan-Ling, T. et al., 1990) (McLeod, D.S. et al., 1987). The hypothesis that the primary retinal vessels are formed via vasculogenesis is based on the observations of "angioblasts" invading the retina before the appearance of differentiated endothelial cells. These vascular precursors have been described as 'spindle-shaped' cells migrating from the optic disc to the retinal periphery. The alignment of these "angioblasts" in vascular cords is followed by lumen formation and differentiation into a primitive vascular network. Finally, via the poorly understood process of remodeling the vessels become mature veins, arteries and capillaries. Until recently, the spindle-shaped cells were only visualized using relatively non-specific stains (Nissl staining, ADPase staining and lectins), as these cells do not express specifics markers of the immature endothelium such as NADPH diaphorase (Provis, J.M. et al., 1997), CD31 (Provis, J.M. et al., 2000), CD34 (Hughes, S. et al., 2000) or VEGFR2 (Fruttiger, M., 2002). In humans, only CD39, a marker of vascular precursors characterized as an ecto-ADPase, has been recently detected in isolated cells in advance of the leading edge of retinal vessels which seems to confirm the idea that angioblasts participate in retinal vascularization (Chan-Ling, T. et al., 2004). However, using a combination of in situ hybridization and immunohistochemistry, it was determined that during the postnatal phases of murine retinal vascularization, no cells beyond the vessels front are positive for VEGFR2 and only the vascular cells express VEGFR2. In contrast, the spindle cells express PDGFR $\alpha$, a marker of astrocytes, which is involved in the expansion and the proliferation of the retinal astrocytes (Fruttiger, M. et al., 1996). Fruttiger proposed that the retina is vascularized in the same manner as the central nervous system by a process entirely angiogenic and that the spindle cells are not angioblasts but are rather astrocytic precursors (Fruttiger, M., 2002). If such a discrepancy in the results could be explained by species specificity, the occurrence of vasculogenesis in the formation of the primary vascular network remains controversial and a definitive answer awaits the unequivocal demonstration of

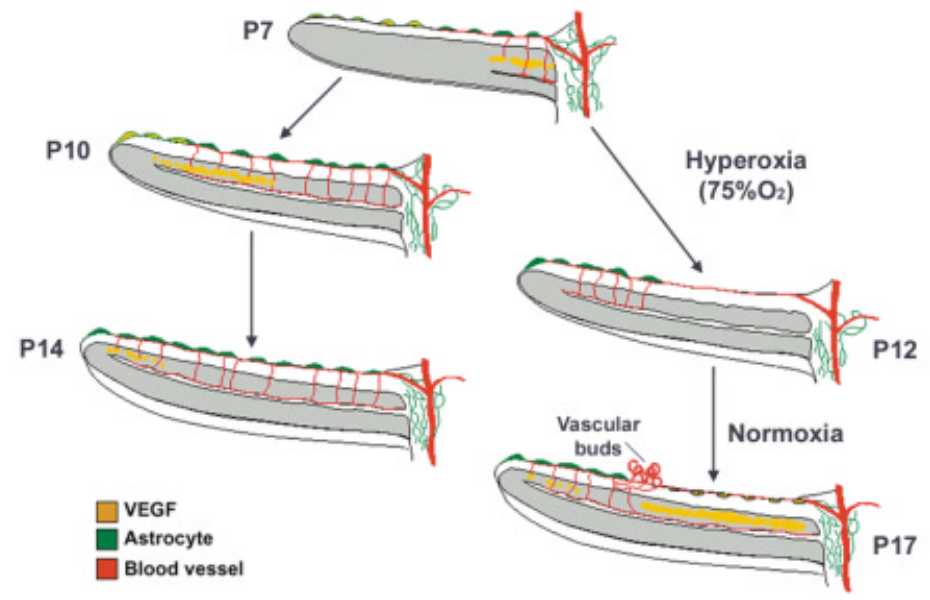

the presence and contribution of endothelial precursors in the process of the retinal vascularization.

An understanding of the major factors involved in the retinal angiogenesis was initially provided by studies of the relationship between the microglia and vascular growth. Retinal vessel development was shown to follow the differentiation of the neural cells and proposed that vascularization depends on an increase in neuronal activity as the retina matures and the associated development of a 'physiologic hypoxia' (Chan-Ling, T. et al., 1995) (Fig. 3). The hypothesis that VEGF is regulated by hypoxia guided the following studies that described the general mechanisms of retinal vascularization (Stone, J. etal., 1995). VEGF expression in the retina is highly controlled both spatially and temporally. During vascularization, VEGF is sequentially expressed by two types of microglia: the astrocytes, in the ganglion cell layer of the retina, and the Müller cells, localized in the internal nuclear layer. The astrocytes and Müller cells participate in the development of the superficial and deep vascular layers, respectively (Stone, J. et al., 1995). As the astrocytes proliferate and differentiate via the PDGF A produced by the neuronal cells, they respond to hypoxia by increasing their synthesis and secretion of VEGF, which in turn induces centrifugal vascular growth along the network formed by the astrocytes.

The ability of hypoxia to induce VEGF expression depends on the binding of the transcription factor hypoxia-inducible factor-1 (HIF-1) to the hypoxia responsive element (HRE) present on the target genes. HIF-1 is a heterodimer composed of the HIF- $1 \alpha$ subunit and a constitutively expressed HIF-1 $\beta$ subunit. The activity of HIF-1 is regulated by the stability of the subunit HIF- $1 \alpha$, which is rapidly degraded under normoxic conditions via the von Hippel-Lindau tumor suppressor gene product ( $\mathrm{pVHL}$ )-mediated ubiquitinproteasome pathway. Hypoxia inhibits HIF-1 $\alpha$ ubiquitinylation and degradation; leading to its accumulation, transfer into the nucleus, and the formation of the HIF-1 complex (for review see Maxwell, P.H. and Ratcliffe, P.J., 2002). An increase in HIF-1 $\alpha$ expression has been shown to be correlated with VEGF expression both during normal and pathologic retinal vascularization in mouse (Ozaki, $\mathrm{H}$. et al., 1997), which confirms the essential role of hypoxia in the regulation of VEGF expression in the retina.

Behind the front of vascularization, the increased oxygen supply suppresses VEGF expression, thereby preventing excessive vascular development. The existence of physiologic hyperoxic zones, such as occur around arteries, leads to the down regulation of VEGF. Since

Fig. 3. Mouse model of retinal vascularization and retinopathy of prematurity (adapted from Stone et al., J. Neuroscience, 1995). (Left) During retinal development, maturation of the neural retina induces a "physiologic hypoxia". Astrocytes spreading from the optic nerve to the periphery respond to the hypoxia by expressing VEGF, which in turn promotes formation of the superficial vascular network. Subsequently, a second wave of neuronal activation induces VEGF secretion in the inner nuclear layer, leading to the formation of the deep vascular layers of the retina. Once the tissue is vascularized, VEGF expression decreases and the new vessels are remodeled and stabilized. (Right) Under hyperoxic conditions, VEGF expression is downregulated before the completion of the normal vascular development, leading to the obliteration of the central retinal vessels. Once returned to normoxia, the unperfused tissue becomes highly hypoxic, inducing a strong and uncontrolled secretion of VEGF and the formation of vascular buds invading the vitreous, characteristic of the pathological neovascularization. 

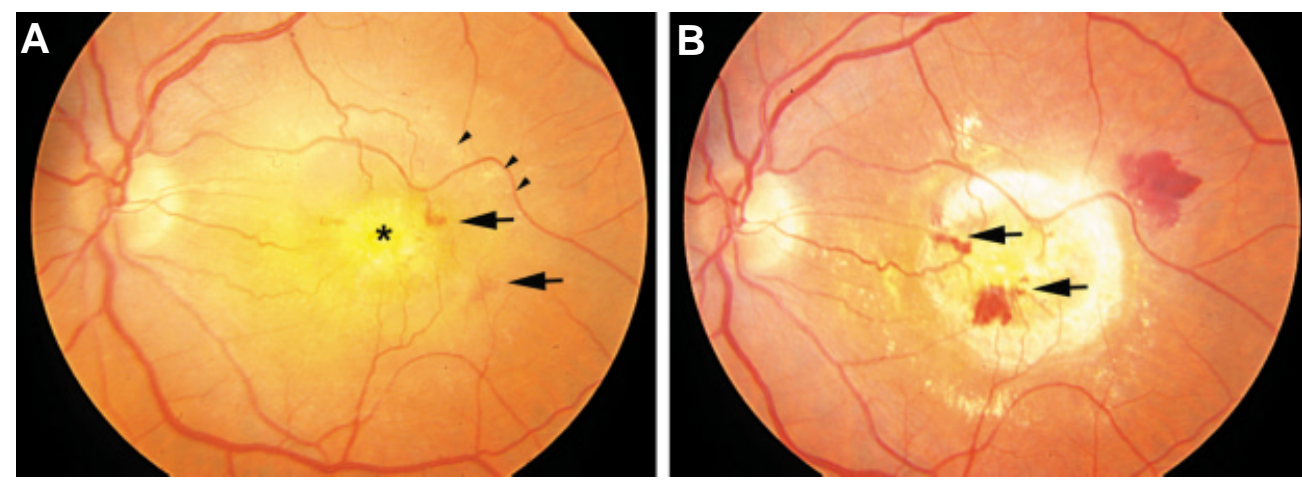

Fig. 4. Clinical examples of choroidal neovascularization associated with agerelated macular degeneration. (A) Fundus shows a yellow-colored submacular lesion with retinal hemorrhages (arrow). Hard drusen (arrowhead) can be observed in the supero-temporal region of the macula (asterisk). (B) Same eye after direct focal photocoagulation. Note the presence of anastamotic vessels connecting the choroidal circulation with the retinal vessels (chorioretinal anastamosis) at the nasaledge of the neovascular membrane (arrow).

VEGF is a well-known endothelial cell survival factor (Alon, T. et al., 1995), the absence of VEGF can induce apoptosis of endothelial cells and thus obliteration of undifferentiated vessels. VEGF depletion during this particular stage, or "plasticity window", is responsible for the pruning and remodeling of the capillary network in order to meet the metabolic needs of the retina. This characteristic plasticity of developing retinal vessels is also responsible for the hypoxiadependent pathologic neovascularization (see Section III. Angiogenesis and ocular pathologies).

The requirement for exogenous VEGF appears to be associated with the lack of pericyte coverage (Benjamin, L.E. etal., 1998). Thus, it appears that the association of nascent vessels can replace the cell requirement for exogenous VEGF. In vitro and in vivo studies have demonstrated that pericytes synthesize and secrete VEGF, which is hypothesized to account for at least a portion of the mechanism by which pericyte-mediated stabilization of vessels occurs (Darland, D.C. et al., 2003). A similar process implicating the Müller cells induces vascularization of the deeper retina. The increase in metabolic demand associated with the activation of the photoreceptors provokes a second round of hypoxia-dependent VEGF secretion, this time by the Müller cell, which leads to the radial sprouting of endothelial cells into the internal layer of the retina (Stone, J. et al., 1995).

Though the essential role of VEGF during retinal vascularization is well established, the functions of the individual VEGF isoforms are still under investigation. Gene targeting that allowed the production of mice expressing a single VEGF isoform strongly suggest that the VEGF isoforms serve distinct roles and functions during angiogenesis (Carmeliet, P. et al., 1996; Stalmans, I. et al., 2002). Mice that express only VEGF 164 display a normal retinal vasculature, indicating that this isoform contains all the "information" needed for the development and organization of the retinal vascular network, whereas mice that express only VEGF120 or VEGF 188 exhibit abnormal retinal vascularization, with reduced vascular outgrowth and defective artery-vein patterning. For example, the retina of VEGF 188/188 mice is characterized by aberrant formation of arterial vessels whereas the veins are normal (Stalmans, I. et al., 2002). Thus, the VEGF isoforms appear to perform specific functions during retinal vascularization.

\section{Angiogenesis and ocular pathologies}

\section{Choroid: age-related macular degeneration}

Age-related macular degeneration (ARMD) represents the primary cause of blindness in individuals 65 and older in the industrialized nations. ARMD is classified as two major forms, the exudative (wet) type (Fig. 4) and the non-exudative (dry) type (Fig. 5). Exudative
ARMD is characterized by the pathologic outgrowth of new vessels from the choroid. Choroidal neovascularization (CNV) extends through Bruch's membrane into the subretinal space. The accumulation of fluid or blood in the posterior part in of retina in association with CNV can lead to the detachment of the RPE or retina, resulting in central vision loss.

Among the several vascular growth factors including VEGF (Frank, R.N. etal., 1996; Kvanta, A. etal., 1996; Lopez, P.F. etal., 1996), bFGF (Frank, R.N. et al., 1996) and TGF- $\beta$ (Amin, R.H. et al., 1997; Kliffen, M. et al., 1997) that have been identified in surgically removed choroidal neovascular membranes, VEGF seems to play a central role in the development of the CNV. VEGF expression has been observed in the RPE and transdifferentiated RPE of human CNV membranes (Frank, R.N. et al., 1996; Lopez, P.F. etal., 1996). In animal models, formation of CNV is associated with increased VEGF expression in the inflammatory cells and proliferative RPE cells at the site of the lesions (Shen, W.Y. et al., 1998) (Ishibashi, T. et al., 1997). Inhibition of VEGF using soluble VEGFR1 (Honda, M. et al., 2000), oligonucleotides (Garrett, K.L. et al., 2001), or neutralizing antibodies (Krzystolik, M.G. et al., 2002) reduces the formation and progression of CNV. Experimental overexpression of VEGF in RPE induces choroidal neovascularization, but the new vessels are restricted to the choroidal space and do not invade Bruch's membrane or the RPE (Schwesinger, C. et al., 2001). The development of new vessels presenting the characteristic clinical features of CNV, including breach of Bruch's membrane and the RPE, has been achieved by sub-retinal injection of viral vectors expressing VEGF (Baffi, J. et al., 2000; Spilsbury, K. et al., 2000; Wang, F. et al., 2003). The different results obtained with transgenic mice and adenovirus infections may be explained by the damage to the Bruch's membrane and the inflammation associated with sub-retinal injection. These observations suggest that the development of invasive CNV requires both the elevated expression of VEGF and the rupture of the Bruch's membrane.

Like VEGF, bFGF has been detected in surgically excised CNV membranes (Frank, R.N. et al., 1996) (Kliffen, M. et al., 1997) and its expression is increased after laser-induced CNV in rats (Ogata, N. et al., 1996). However, a direct role for bFGF in the progression of CNV is unclear as studies with bFGF knock-out mice revealed that the absence of bFGF does not affect the formation of experimental CNV (Tobe, T. et al., 1998). Yamada et al., demonstrated that overexpression of bFGF by the photoreceptors can lead to CNV after disruption of Bruch's membrane and the photoreceptors by laser photocoagulation (Yamada, H. et al., 2000), suggesting that the angiogenic potential of bFGF depends 
on a cellular injury and release of the growth factor into the extracellular space.

If RPE-derived growth factors appear to be critical in the development of CNV, the role of the RPE in wet AMD is still controversial. Some studies have suggested that the presence of RPE can reduce CNV or even induce vascular regression (Miller, H. et al., 1986; Takahashi, T. et al., 2000). This dual function of RPE cells in promoting both the development and regression of the CNV is interestingly reflected by the paradoxical functions of pigment-epithelial derived factor (PEDF) on endothelial cells. Like VEGF, PEDF is constitutively expressed by the RPE cells. Initially described as an inhibitor of neuronal differentiation, PEDF has been shown to be a potent anti-angiogenic factor and is in part responsible for the anti-angiogenic properties of the vitreous (Dawson, D.W. et al., 1999). One attractive characteristic of this PEDF is its regulation by oxygen. In contrast to VEGF, which is induced by low oxygen, hypoxia suppresses PEDF expression. This leads to an inversion of the VEGF/PEDF ratio (Gao, G. et al., 2001), which may promote angiogenesis. The efficacy of PEDF in inhibiting neovascularization has been clearly demonstrated in numerous models of AMD and retinal neovascularization. However, the true contribution of PEDF to choroidal neovascularization is unclear. Some studies reported that PEDF levels are reduced in the vitreous of AMD patients (Holekamp, N.M. et al., 2002), suggesting that the loss of this inhibitor associated with an increase of angiogenic-factors could potentiate choroidal neovascularization. At the same time, other studies have suggested that PEDF secretion could participate in CNV. For example, high levels of PEDF are associated with both active neovascularization in proliferative diabetic retinopathy (Duh, E.J. et al., 2004) and in laser-induced CNV in the rat (Ogata, N. et al., 2002; Renno, R.Z. etal., 2002). An angiogenic function of PEDF has been suggested by in vitrostudies showing that PEDF can induce the proliferation of bovine retinal endothelial cells pre-exposed to VEGF (Hutchings, H. et al., 2002). A better comprehension of the opposite role of PEDF on endothelial cells will depend on the characterization of the molecular mechanisms mediating PEDF action on vascular cells.

The advanced form of dry AMD or geographic atrophy (GA) is also a cause of severe visual loss in patients with ARMD (Fig. 5). In GA, there is localized degeneration of the RPE with atrophy of the overlying photoreceptors and the underlying choriocapillaris. On fluorescein angiography, GA appears as a discrete area of hyperfluorescence. GA can also progress to a wet form of AMD, as $34 \%$ of the patients with GA eventually present CNV (Green, W.R. and Enger, C., 1993). GA often develops in the macular areas just outside the fovea and progresses into the foveal center in its late stage. A patient's visual problems are directly related to development of visual blind spots (scotomas) within the central visual field. Histopathological studies of eyes with GA show isolated areas of RPE loss, and it has been speculated that the loss of the choriocapillaris is secondary to the absence of RPE (Sarks, J.P. et al., 1988) (McLeod, D.S. et al., 2002). Clinical observations reveal that early changes in the RPE layer precede the atrophy of the choriocapillaris in AMD, suggesting that choriocapillaris pathology is secondary to RPE lesions (Sarks, S.H., 1976; Young, R.W., 1987). In addition, studies of animal models have demonstrated that chemical or mechanical destruction of the RPE leads to loss of fenestrations and atrophy of the underlying choroidal vessels (Korte, G.E. et al., 1984; Del Priore, L.V. etal., 1995). Interestingly, the remaining choriocapillaris acquire an altered phenotype, lacking the typical capillary fenestrae and becoming encased in dense, collagenous connective tissue. Similarly, abrasive removal of the RPE has been demonstrated to cause ultrastructural alterations in the underlying Bruch's membrane and choriocapillaris complex, closely representing clinical GA (Leonard, D.S. et al., 2003). Together, these data suggest that the crucial relationship between the RPE and the choroidal vessels observed during development persists in the adult.

Among the different growth factors expressed by the RPE, VEGF is a good candidate for mediating RPE survival effects on choroidal vessels. In humans, it has been shown that RPE in vivo secrete VEGF basally (toward the choriocapillaris) and that VEGF receptors are expressed on the choroidal endothelium facing the RPE layer (Blaauwgeers, H.G. et al., 1999). These observations suggest that VEGF signaling occurs in the quiescent choriocapillaris. VEGF acts as a survival factor for developing retinal vessels in vivo (Alon, T. et al., 1995) and its withdrawal during the postnatal period leads to endothelial cell apoptosis in vitro (Gerber, H.-P. et al., 1999; Chow, J. et al., 2001) and in vivo (Gerber, H.-P. et al., 1999). Thus, RPE-secreted VEGF could
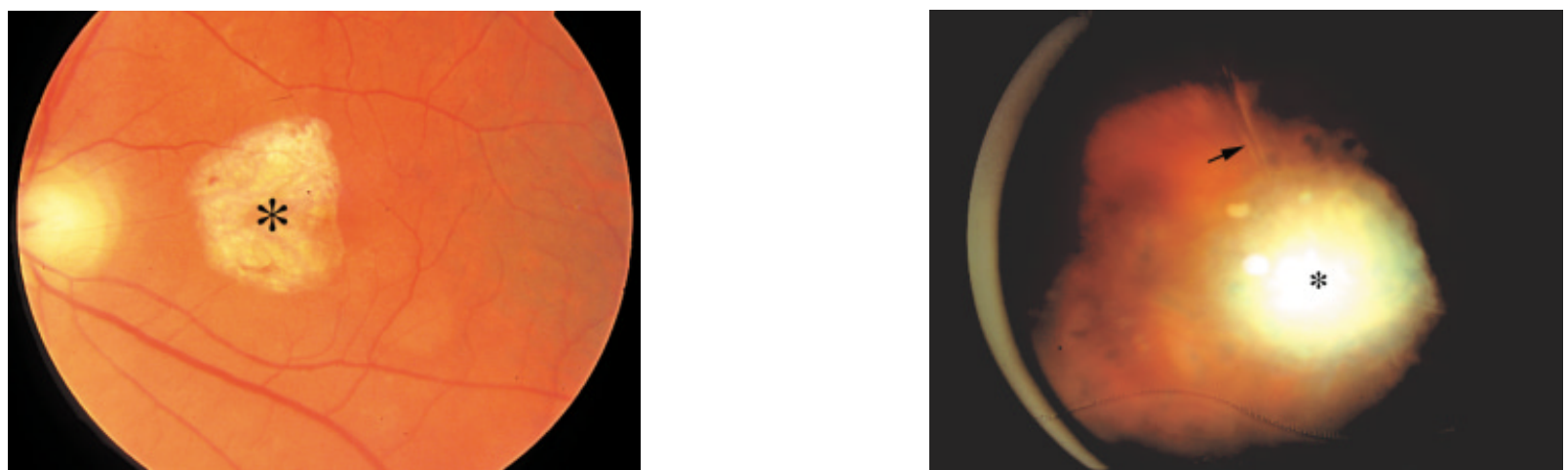

Fig. 5 (Left). Fundus of human eye with geographic atrophy associated with age-related macular degeneration. The white atrophic zone (asterisk) extends to the nasal part of the fovea and is associated with degeneration of the retinal outer-layers, the RPE and the underlying choroidal vessels.

Fig. 6 (Right). Clinical example of persistent fetal vasculature (PVF). Fundus of an eye showing the persistent hyaloid artery with a whitish retrolental scar attached to the posterior surface of the lens (asterisk). Note the disorganization and the tearing of the retina (arrow). 
Fig. 7. Two examples of Retinopathy of Prematurity (ROP). (A) Fundus of a stage 3 threshold plus disease showing dilated retinal vessels. Patient has been treated with laser photocoagulation of the avascular retina. (B) Example of an advanced ROP stage $4 A B$ (total retinal detachment) disease. Note the central neovascularization associated with hemorrhage (asterisk), while the periphery of the retina remains avascular (arrow).
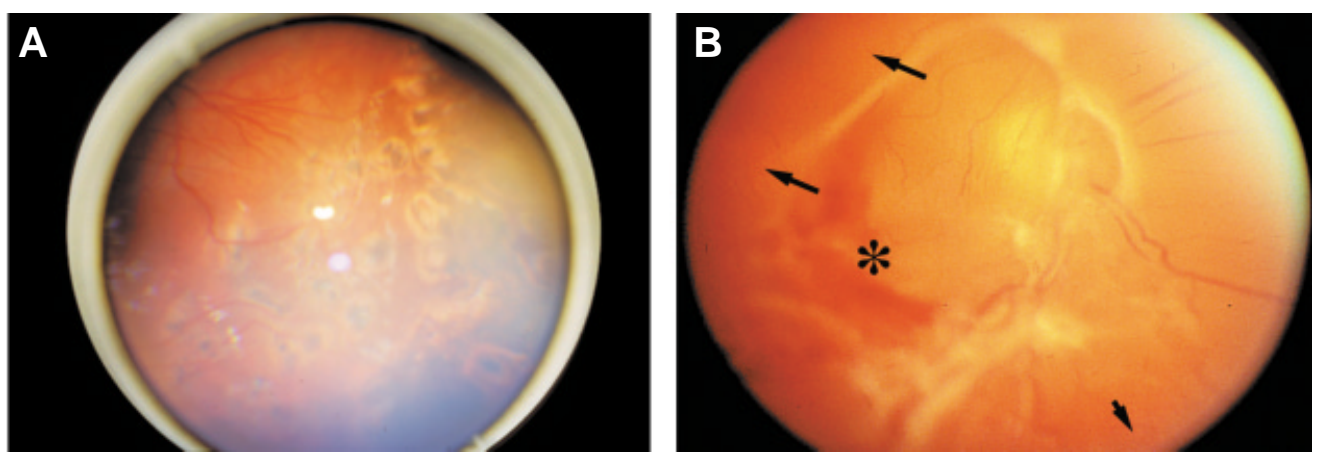

represent a survival factor for quiescent choriocapillaris, which would account for the choroidal atrophy observed after loss of the RPE. A modification of the paracrine signals between RPE and the choroid could be involved in the atrophy of the choriocapillaris observed in GA. With age, the Bruch's membrane undergoes important changes such as an important thickening (Ramrattan, R.S. et al., 1994) and decrease of permeability (Moore, D.J. et al., 1995) that alter its normal function. It is possible that as the Bruch's membrane becomes less permeable to secreted molecules, RPE-expressed VEGF is not able to diffuse to the choriocapillaris, resulting in their atrophy.

Such a regression of the choriocapillaris observed in dry AMD could be also the initial event inducing the development of CNV. The association of localized hypoxia leading to VEGF overexpression with the damage of the Bruch's membrane due to the accumulation debris could under certain conditions evolve in a secondary neovascularization. Thus, the fate of the choroidal vessels depends on multiple cellular and molecular factors that reflect the complex etiology and outcome of the pathology.

\section{Hyaloid: persistence of hyaloid vasculature}

Failure of the hyaloid vasculature to completely regress is associated with several ocular pathologies referred to as hyperplastic primary vitreous or persistent fetal vasculature (Fig. 6). This condition is associated with severe intraocular hemorrhage, retinal detachment and cataract (Goldberg, M.F., 1997). Despite its clinical importance, cellular and molecular processes involved in the normal involution of the hyaloid vessels remain unclear. One hypothesis suggests that apoptosis of the endothelial cells and pericytes could be initiated by a decrease in VEGF expression by the lens (Mitchell, C.A. et al., 1998). However, recent findings revealed that not only is VEGF expression increased in the lens during the regression of the hyaloid vascular system (HVS) but also it persists in the adult (Shui, Y.B. etal., 2003). Thus, it seems unlikely that the induction of the apoptotic events is associated with a loss of VEGF as a survival factor. This conclusion is supported by the fact that injection of VEGF into the anterior chamber has a limited protective effect on the regression of the PM (Meeson, A.P. et al., 1999). Several studies have suggested that macrophages are required for the regression of the HVS. Presence of numerous macrophages inside the vitreous and associated with the hyaloid vessels has been documented by electron microscopy and immunostaining (Lang, R.A. and Bishop, J.M., 1993; Lang, R. et al., 1994; Ito, M. and Yoshioka, M., 1999; Perou, C. et al., 1999). Based on intravitral microscopy, it has been proposed that the regression of the PM is divided in a twostep process: an initiating apoptosis that is dependent on the activity of the macrophages, followed by the synchronous death of the endothelial cells as a direct consequence of the cessation of blood flow and/or the loss of survival factors such as VEGF (Meeson, A. et al., 1996; Meeson, A.P. et al., 1999). This model could be extended to the HSV where the vasoconstriction of the proximal hyaloid arteries precedes the involution of the hyaloid network (Browning, J. et al., 2001).

The signals or process initiating the transition to apoptosis and the activation of the macrophages in the HVS are still unknown. Studies based on the analysis of transgenic animals have implicated numerous growth factors and molecules in the progression of the hyaloid vessels regression (see Table 1), including LRP5 (Kato, M. et al., 2002), Arf (McKeller, R.N. et al.,

TABLE I

\section{MOUSE MODELS OF PERSISTENT HYALOID VESSELS}

\begin{tabular}{|c|c|c|c|c|}
\hline Gene & Transgenic mice & Morphology of the HSV & Vascularization of the retina & References \\
\hline Lrp5 (Wnt receptor) & $\mathrm{KO}$ & Persistence throughout life & ND & Kato et al., JCR, 2002 \\
\hline Frizzled-4 & $\mathrm{KO}$ & Delayed regression & Defective vascularization & Xu et al., Cell, 2004 \\
\hline Arf (Tumor supressor) & $\mathrm{KO}$ & $\begin{array}{l}\text { Persistence with secondary anomalie } \\
\text { of lens and retina (like PHPV) }\end{array}$ & ND & McKeller et al., PNAS, USA, 2002 \\
\hline Collagen 18 & $\mathrm{KO}$ & Delayed regression & Defective vascularization & Fukai et al., EMBO J., 2002 \\
\hline FGFR1 Dominant Negative & Overexpression in RPE & Persistence & No vascularization & Rousseau et al., Exp. Eye. Res., 2003 \\
\hline VEGF isoform 188 & & Persistence & Defective vascularization & Stalmans et al., J. Clin. Invest., 2003 \\
\hline Ang2 & $\mathrm{KO}$ & Persistence & Complete vasculature & Hackett et al., J. Cell. Physiol., 2002 \\
\hline BMP-4 & Heterozygote +/- & $\begin{array}{l}\text { Persistence associated with } \\
\text { absence of macrophages }\end{array}$ & Abnormal retinal vessels & Chang et al., BMC Genet., 2001 \\
\hline
\end{tabular}


2002), collagen XVIII (Fukai, N. etal., 2002), bFGF (Rousseau, B. etal., 2003), VEGF 188 (Stalmans, I. etal., 2002) and angiopoietin2 (Gale, N.W. et al., 2002; Hackett, S.F. et al., 2002). However, in these models, the persistence of the HSV is often associated with the defect of the retinal vascularization, suggesting that in some cases, hyaloid vessels could persist to compensate for the absence or lack of retinal vessels. Thus, the real role for these molecules in HSV regression must be determined in a context independent of retinal vascular abnormalities.

\section{Proliferative retinopathies}

Under normal circumstances, the blood vessels of the retina, though metabolically active, are quiescent with respect to growth (Engerman, R.L. et al., 1967). However, there are a variety of retinal pathologies characterized by rapid vessel proliferation including, proliferative diabetic retinopathy, venous occlusion, and retinopathy of prematurity (ROP). These pathologies are all characterized by the presence of non-perfused, and therefore hypoxic, retinal tissue as a precedent to the neovascularization. Realizing that ischemia may contribute to the disease process and knowing that VEGF expression can be regulated by local oxygen levels, a number of laboratories, using various experimental models, have examined the role of VEGF in retinal neovascular diseases.

\section{Retinopathy of prematurity}

A role for VEGF in the pathogeneses of ROP has been clearly established. As described earlier, analysis of the cat and mouse retina has revealed that astrocytes migrate into the developing postnatal retina in front of the forming vasculature (Stone, $\mathrm{J}$. et al., 1996). A "physiologic hypoxia" develops, due to the increased metabolic demands of the differentiating neural retina, leading to upregulation of astrocyte VEGF production (Fig. 3). The gradient of VEGF thus produced mediates continued vascularization of the ganglion cell layer. Synthesis of VEGF by the Müller cells, also stimulated by local oxygen deficit, induces the sprouting of the vasculature downward into the inner nuclear layer. Once metabolic demands are met, hypoxia subsides and VEGF expression declines.

Because vascularization of the human retina takes place in the final trimester of gestation, a premature infant has an incompletely vascularized retina in which "physiologic hypoxia" has induced VEGF. Placement of an infant into high oxygen to alleviate respiratory distress suppresses VEGF expression. The reduced in VEGF leads to the cessation of vessel growth and the regression of nascent vessels that are still dependent on exogenous VEGF for their survival, a phase of ROP termed "vaso-obliteration". Once the infant is returned to room air, the retina becomes hypoxic, leading to VEGF upregulation and new vessel growth (Fig. 7).

A mouse model of ROP has been established (Smith, L.E.H. et al., 1994) and is widely used. In this model, neonatal mice are reared in a high oxygen environment for 5 days and then returned to room air. Examination of the retinas of these mice upon removal to room air reveals significant areas of non-perfusion and is followed in the next 3-5 days by the growth of new vessels (Figs. 8,9). The retinas of neonatal mice incubated in high oxygen and then returned to room air had elevated levels of VEGF mRNA that was localized to Müller cells in the inner nuclear layer (Pierce, E.A. et al., 1995). A causal link between VEGF expression and the observed neovascularization was demonstrated when the vessel growth was shown to be suppressed by the injection of soluble VEGF receptor chimeric proteins that block VEGF activity (Aiello, L.P. et al., 1995). Since the neovascularization had been shown to be due to hypoxia-induced VEGF, it was suspected that oxygen levels might be titrated to be high enough to prevent hypoxic damage to the retina but not so high as to suppress the VEGF expression required for normal retinal vascularization. This balance was shown to be effective in the kitten model of ROP (Chan-Ling, T. et al., 1995) and is now the focus of clinical trials for the treatment of human ROP. Further insight into the involvement of VEGF in the pathogenesis of ROP came from studies using a cat model of the disease. The vaso-obliterative phase of ROP was shown to be due to the suppression of VEGF expression by neuroglial cells by the elevated oxygen. Since the VEGF directs normal vascularization of the retina and is necessary for vessel stability during the nascent stage of vessel formation, its absence
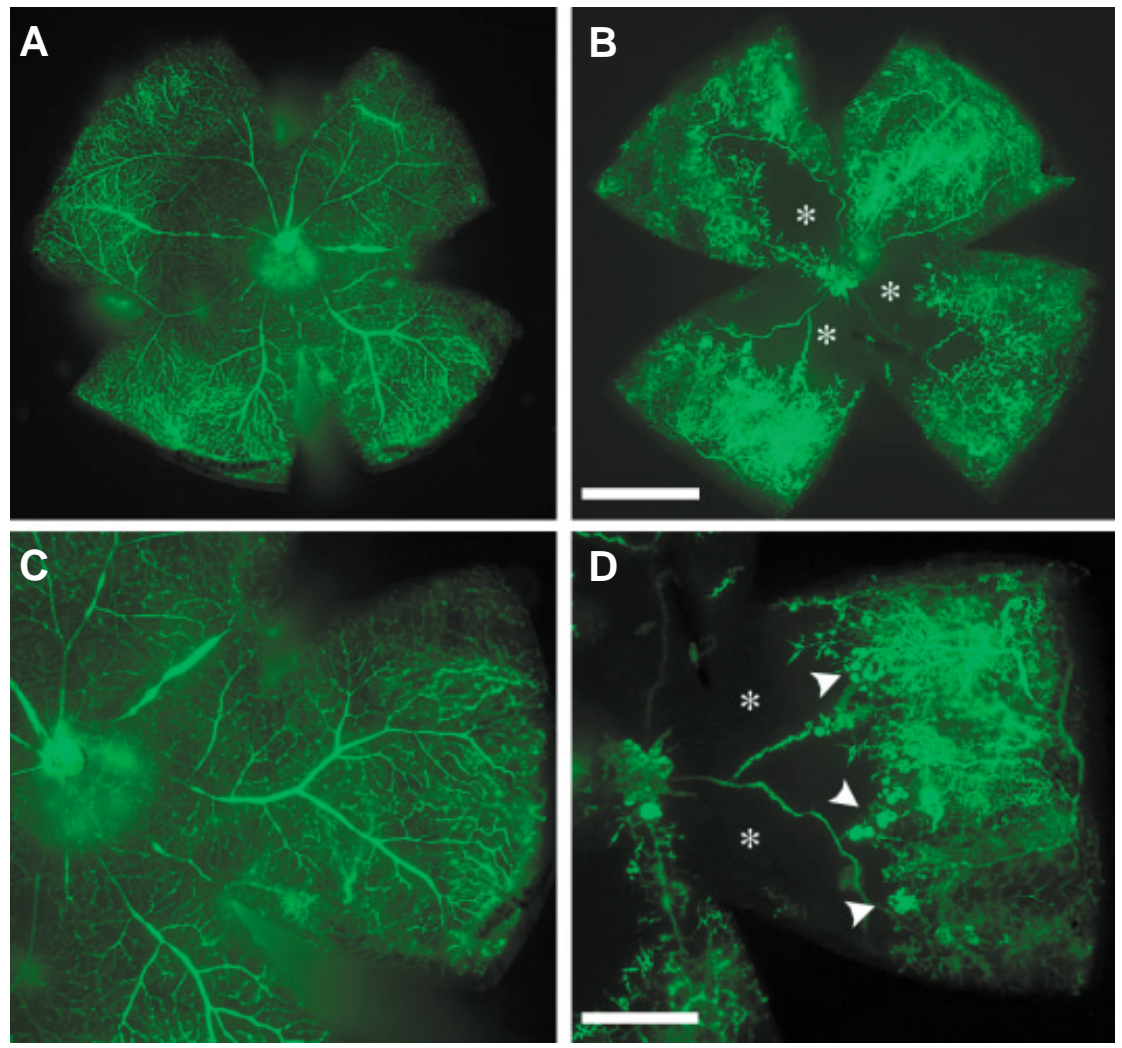

Fig. 8. Fluorescein-dextran perfused retinas of mice exposed to room air or hyperoxia. $(\mathbf{A}, \mathbf{C})$ retina from $P 17$ room air-raised mouse showing the normal pattern of retinal vessels. (B,D) retina from $P 17$ mouse exposed to $75 \%$ oxygen from $P 7$ to $P 12$. Stars indicate the central hypoperfusion induced by hyperoxia. Arrows point to the neovascular tufts extending into the vitreous. (A,B) Magnification bar represents $1 \mathrm{~mm}$. (C,D) Bar represents $500 \mu \mathrm{m}$. 
A

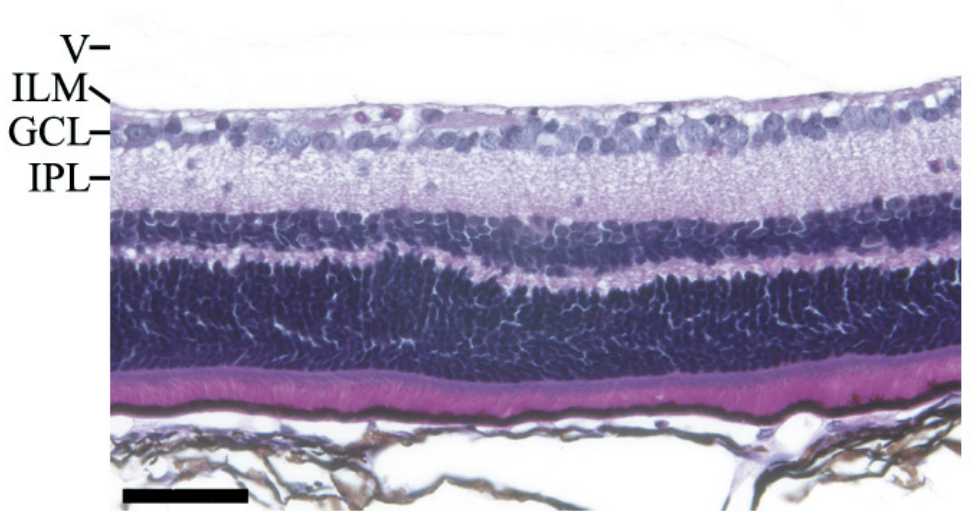

B

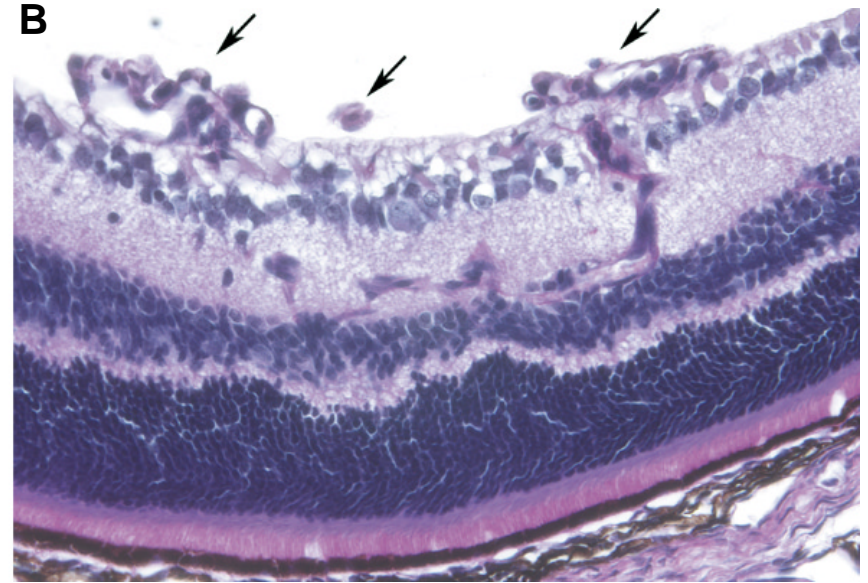

Fig. 9. Proliferative neovascular response to hyperoxia. Eight $\mu \mathrm{m}$ paraffin cross-sections of C57BL/6 mice retinas stained with PAS and hematoxylin. (A) 17 day old C57BL/6 control mouse exposed to room air. (B) 17 day old mouse exposed to $75 \%$ oxygen from $p 7$ to $p 12$ before returning to room air. Arrows indicate neovascular tufts extending into the vitreous. Bar represents $100 \mu \mathrm{m}$. V, vitreous; ILM, internal limiting membrane; GCL, ganglion cell layer; IPL inner plexiform layer.

leads to areas of vessel loss. Vessel regression was shown to occur via apoptosis, pointing to a role for VEGF as a survival factor in vivo. Upon return to room air, the absence of vessels provokes retinal hypoxia, elevated VEGF production and the growth of new vessels, similar to that seen in human infants.

\section{Diabetic retinopathy}

Ocular pathology is one of the many devastating complications of both Type I and Type 2 diabetes. Early changes in the retinal vasculature include vessel dilation, increased permeability, basement membrane thickening, loss of pericytes and formation of microaneurysms (for review see Frank, R.N., 2004). This myriad of vascular changes reflects the chronic damage sustained by the vasculature as a result of metabolic alterations, including hyperglycemia, associated with diabetes. These changes lead to vascular dysfunction and loss. Though the nature of the dysfunction is not entirely understood it appears to include alterations in complement deposition and expression of leukocyte adhesion molecules (for review see Lorenzi, M. and Gerhardinger, C., 2001). The ischemia that results from the loss of vessel perfusion leads to increased VEGF expression and vessel growth (Fig. 10). These new vessels grow outside the retina and into the vitreous. In addition, these new vessels are leaky, due in part to the permeability-inducing effects of VEGF. Formation of a fibrous membrane, in combination with traction caused by vitreous attachments, can lead to retinal detachment. The predominant treatment for proliferative diabetic retinopathy (PDR), laser photocoagulation, directed at the avascular retina, frequently leads to vessel regression. This effect is likely due to the fact that the treatment destroys the source of the angiogenic/permeability factor, thus removing the VEGF required for stabilization of the nascent vessels.

There are no animal models of PDR. As the injury that leads to this complication in humans occurs over many years, it is likely that the lifespan of the rodents (mice and rats) that are most commonly used is not long enough to accumulate the "needed" neural and vascular alterations. As an alternative ischemiainduced neovascularization is used as a model of PDR. Using a modification of a model of retinal ischemia-induced iris neovascularization (Virdi, P.S. and Hayreh, S.S., 1982), the expression of VEGF was examined in the cynomologous money retina, which had been rendered ischemic by laser occlusion of the branch retinal veins (Miller, J.W. et al., 1994). Seven to fourteen days following the occlusion, new blood vessels grow on the surface of the iris. (This is similar to rubeosis iridis, which occurs in diabetics and is associated with retinal capillary nonperfusion). VEGF protein and mRNA levels were shown to correlate with the timing and severity of iris angiogenesis. PCR analysis revealed that the retina was producing the 121 and 165 amino acid isoforms of VEGF, the more diffusible forms relative to the third known isoform VEGF189 (Shima, D.T. etal., 1996). (Primate VEGF isoforms have one amino acid more than the rodent
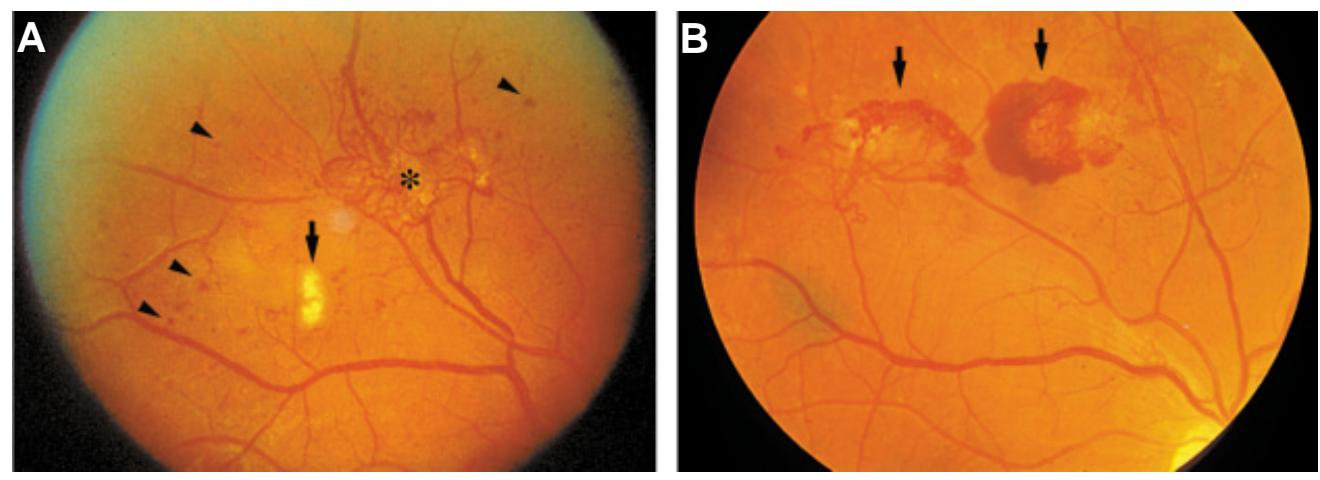

Fig. 10. Examples of proliferative diabetic retinopathy (PDR). (A) The large central retinal neovascularization (asterisk) is associated with exudates (seen as yellow), and microaneurysms (arrowhead). (B) Characteristic "sea fan" configuration of the retinal neovascularization associated with PDR (arrow). In both examples, note the irregularities and dilatation of the major veins and arteries. 
counterparts.) In situ hybridization demonstrated VEGF mRNA expression by the ganglion cells of the retinal ganglion cell layer and by another cell type, possibly amacrine cells, in the inner nuclear layer (Shima, D.T. et al., 1996). This expression pattern is consistent with the concept that expression is regulated by hypoxia because these cells are located in the inner retina which is the tissue normally served by the occluded vessels. A necessary role for VEGF in this process was demonstrated by studies in which neutralizing monoclonal antibodies against VEGF were administered intra-vitreally at the time of vein occlusion and every other day thereafter (Adamis, A.P. et al., 1996) for 14 days. The vitreous of eyes with proliferative diabetic retinopathy has been shown to have levels of VEGF significantly higher than vitreous from eyes without proliferative retinopathy (Adamis, A.P. et al., 1994; Aiello, L.P. et al., 1994; Malecaze, F. et al., 1994) and neovascular membranes were shown to have VEGF mRNA (Malecaze, F. et al., 1994).

\section{Summary}

Developmental ocular vascularization is a complex process which requires the strict coordination of numerous molecular and cellular interactions. However, many of the regulators involved in the angiogenic process are still unknown. Further investigations are needed to improve our understanding of the basic mechanisms of blood vessel formation. This information is important not only to further our understanding of vascular development but because pathologic processes frequently mimic those of development. For example, the already well-known vascular functions of VEGF and its receptors have led to the creation of innovative and promising strategies for the treatment of neovascular pathologies. These new strategies, based on the inactivation of VEGF signaling, are currently in clinical trials for ophthalmic diseases such as AMD and diabetic maculopathy. One of today's challenges is to improve the safety and efficiency of these new drugs. As we have described here, VEGF functions are not limited to active angiogenesis, but also seem to be required for the maintenance and the differentiation of mature blood vessels such as the choriocapillaris. Therefore, delivery of these anti-VEGF treatments needs to be specific to sites of neovascularization or limited to a short duration to prevent disruption of the normal vasculature. Thus, knowledge of the developmental regulation of the vasculature will not only expand our understanding of ocular development but will also support the advancement of new therapeutic approaches.

\section{Acknowledgements}

The authors thank Chris Bagley for her constant support and assistance. Fundus photographs were generously provided by Dr. Kameran Lashkari. The D'Amore laboratory is supported by EY05318, EY015435, CA45548 and a grant from the Juvenile Diabetes Research Foundation.

\section{References}

ADAMIS, A.P., MILLER, J.W., BERNAL, M.-T., D'AMICO, D.J., FOLKMAN, J., YEO, T.-K. and YEO, K.-T. (1994). Increased vascular endothelial growth factor levels in the vitreous of eyes with proliferative diabetic retinopathy. Am. J. Ophthal. 118: 445-450.

ADAMIS, A.P., SHIMA, D.T., TOLENTINO, M.J., GRAGOUDAS, E.S., FERRARA, N., FOLKMAN, J., D'AMORE, P.A. and MILLER, J.W. (1996). Inhibition of VEGF prevents ocular neovascularization in a primate. Arch. Ophthalmol. 114: 66-71.
AIELLO, L.P., AVERY, R.L., ARRIGG, P.G., KEYT, B.A., H.D., J., SHAH, S.T., PASQUALE, L.R., THIEME, H., IWAMOTO, M.A., PARK, J.E., NGUYEN, H.V., AIELLO, L.M., FERRARA, N. and KING, G.L. (1994). Vascular endothelial growth factor in ocular fluid of patients with diabetic retinopathy and other ocular disorders. New Engl. J. Med. 331: 1480-1487.

AIELlO, L.P., PEIRCE, E.A., FOLEY, E.D., TAKAGI, H., CHEN, H., RIDDLE, L., FERRARA, N., KING, G.L. and SMITH, L.E.H. (1995). Suppression of retinal neovascularization in vivo by inhibition of vascular endothelial growth factor (VEGF) using soluble VEGF-receptor chimeric proteins. Proc. Natl. Acad. Sci. USA 92: 10457-10461.

ALON, T., HEMO, I., ITIN, A., PE'ER, J., STONE, J. and KESHET, S. (1995). Vascular endothelial growth factor acts as a survival factor for newly formed retinal vessels and has implications for retinopathy of prematurity. Nature Medicine1:1024-1028.

AMBATI, J., AMBATI, B., YOO, S., IANCHULEV, S. and ADAMIS, A. (2003). Agerelated macular degeneration: etiology, pathogenesis, and therapeutic strategies. Surv Ophthalmol. 48: 257-293.

AMIN, R.H., FRANK, R.N., KENNEDY, A., ELIOTT, D., PUKLIN, J.E. and ABRAMS, G.W. (1997). Vascular endothelial growth factor is present in glial cells of the retina and optic nerve of human subjects with nonproliferative diabetic retinopathy. Invest Ophthalmol Vis Sci38: 36-47.

ASH, J.D. and OVERBEEK, P.A. (2000). Lens-specific VEGF-A expression induces angioblast migration and proliferation and stimulates angiogenic remodeling. Dev Bio/223: 383-398.

BACIC, M., EDWARDS, N.A. and MERRILL, M.J. (1995). Differential expression of vascular endothelial growth factor (vascular permeability factor) forms in rat tissues. Growth Factors 12: 11-15.

BAFFI, J., BYRNES, G., CHAN, C.C. and CSAKY, K.G. (2000). Choroidal neovascularization in the rat induced by adenovirus mediated expression of vascular endothelial growth factor. Invest Ophthalmol Vis Sci 41: 3582-3589.

BENJAMIN, L.E., HEMO, I. and KESHET, E. (1998). A plasticity window for blood vessel remodelling is defined by pericyte coverage of the preformed endothelial network and is regulated by PDGF-B and VEGF. Development 125: 1591-1598.

BLAAUWGEERS, H.G., HOLTKAMP, G.M., RUTTEN, H., WITMER, A.N., KOOLWIJK, P., PARTANEN, T.A., AlitAlo, K., KROON, M.E., KIJLSTRA, A., VAN HINSBERGH, V.W. and SCHLINGEMANN, R.O. (1999). Polarized vascular endothelial growth factor secretion by human retinal pigment epithelium and localization of vascular endothelial growth factor receptors on the inner choriocapillaris. Evidence for a trophic paracrine relation. Am J Patho/155: 421 428.

BOTTINGER, E., LETTERIO, J. and ROBERTS, A. (1997). Biology of TGF- $\beta$ in knockout and transgenic mouse models. Kid. Internat. 51: 1355-1360.

BROWNING, J., REICHELT, M.E., GOLE, G.A. and MASSA, H. (2001). Proximal arterial vasoconstriction precedes regression of the hyaloid vasculature. Curr Eye Res 22: 405-411.

CARMELIET, P., FERRIERA, V., BREIER, G., POLLEFEYT, S., KIECKENS, L., GERTSENSTEIN, M., FAHRIG, M., VANDENHOECK, A., HARPAL, K., EBERHARDT, C., DECLERCQ, C., PAWLING, J., MOONS, L., COLLEN, D., RISAU, W. and NAGY, A. (1996). Abnormal blood vessel development and lethality in embryos lacking a single VEGF allele. Nature 380: 435-439.

CHAN-LING, T., GOCK, B. and STONE, J. (1995). The effect of oxygen on vasoformative cell division. Evidence that 'physiologic hypoxia' is the stimulus for normal retinal vasculogenesis. Invest. Ophthalmol. Vis. Sci. 36: 1201-1214.

CHAN-LING, T., GOCK, B. and STONE, J. (1995). Supplemental oxygen therapy. Basis for noninvasive treatement of retinopathy of prematurity. Invest. Opthalmol. Vis. Sci. 36: 1215-1230.

CHAN-LING, T., HALASZ, P. and STONE, J. (1990). Development of retinal vasculature in the cat: processes and mechanisms. Cur. Eye Res. 9: 459-478.

CHAN-LING, T., MCLEOD, D.S., HUGHES, S., BAXTER, L., CHU, Y., HASEGAWA T. and LUTTY, G.A. (2004). Astrocyte-Endothelial Cell Relationships during Human Retinal Vascular Development. Invest Ophthalmo/ Vis Sci45: 2020-2032.

CHANG, B., SMITH, R.S., PETERS, M., SAVINOVA, O.V., HAWES, N.L., ZABALETA, A., NUSINOWITZ, S., MARTIN, J.E., DAVISSON, M.L., CEPKO, C.L., HOGAN, B.L. and JOHN, S.W. (2001). Haploinsufficient Bmp4 ocular phenotypes include anterior segment dysgenesis with elevated intraocular pressure. BMC Genet2: 18.

CHOW, J., OGUNSHOLA, O., FAN, S.Y., LI, Y., MENT, L.R. and MADRI, J.A. (2001). Astrocyte-derived VEGF mediates survival and tube stabilization of hypoxic brain microvascular endothelial cells in vitro. Brain Res Dev Brain Res 130: 123-132. 
COFFIN, J.D. and POOLE, T.J. (1988). Embryonic vascular development: immunohistochemical identification of the origin and subsequent morphogenesis of the major vessel primordia in quail embryo. Development 102: 1-14.

DARLAND, D.C. and D'AMORE, P.A. (2001). Cell-cell interactions in vascular development. Curr Top Dev Bio/52: 107-149.

DARLAND, D.C., MASSINGHAM, L.J., SMITH, S.R., PIEK, E., SAINT-GENIEZ, M. and D'AMORE, P.A. (2003). Pericyte production of cell-associated VEGF is differentiation-dependent and is associated with endothelial survival. Dev Biol 264: 275-288.

DAWSON, D.W., VOLPERT, O.V., GILLIS, P., CRAWFORD, S.E., XU, H., BENEDICT, W. and BOUCK, N.P. (1999). Pigment epithelium-derived factor: a potent inhibitor of angiogenesis. Science 285: 245-248.

DEL PRIORE, L.V., HORNBECK, R., KAPLAN, H.J., JONES, Z., VALENTINO, T.L., MOSINGER-OGILVIE, J. and SWINN, M. (1995). Debridement of the pig retinal pigment epithelium in vivo. Arch Ophthalmo/113: 939-944.

DOETSCHMAN, T.A., GOSSLER, A. and KEMLER, R. (1987). Blastocyst-derived embryonic stem cells as a model for embryogenesis. Future Aspects in Human In Vitro Fertilization. FEICHTINGEN, W. and KEMETER, P. Berlin, Springer-Verlag: 187-195.

DREHER, Z., ROBINSON, S.R. and DISTLER, C. (1992). Muller cells in vascular and avascular retinae: a survey of seven mammals. J Comp Neuro/323: 59-80.

DUH, E.J., YANG, H.S., HALLER, J.A., DE JUAN, E., HUMAYUN, M.S., GEHLBACH, P., MELIA, M., PIERAMICI, D., HARLAN, J.B., CAMPOCHIARO, P.A., ZACK, D.J., OGATA, N., WADA, M., OTSUJI, T., JO, N., TOMBRAN-TINK, J., MATSUMURA, M., DAWSON, D.W., VOLPERT, O.V., GILLIS, P., CRAWFORD, S.E., XU, H., BENEDICT, W. and BOUCK, N.P. (2004). Vitreous levels of pigment epithelium-derived factor and vascular endothelial growth factor: implications for ocular angiogenesis. Am J Ophthalmo/137: 668-674.

DUMONT, D.J., GRADWOHL, G., FONG, G.-H., PURI, M.C., GERTSENSTEIN, M., AUERBACH, A. and BREITMAN, M.L. (1994). Dominant-negative and targeted null mutations in the endothelial receptor tyrosine kinase, tek, reveal a critical role in vasculogenesis of the embryo. Genes Dev. 8: 1897-1907.

ENGERMAN, R.L., PFAFFENBACH, D. and DAVIS, M.D. (1967). Cell turnover of capillaries. Lab. Invest. 17: 738-743.

ETCHEVERS, H.C., VINCENT, C., LE DOUARIN, N.M. and COULY, G.F. (2001). The cephalic neural crest provides pericytes and smooth muscle cells to all blood vessels of the face and forebrain. Development 128: 1059-1068.

FLOWER, R.W., MCLEOD, D.S., LUTTY, G.A., GOLDBERG, B. and WAJER, S.D. (1985). Postnatal retinal vascular development of the puppy. Invest Ophthalmol Vis Sci26: 957-968.

FRANK, R.N. (2004). Diabetic retinopathy. N Eng/J Med350: 48-58.

FRANK, R.N., AMIN, R.H., ELIOTT, D., PUKLIN, J.E. and ABRAMS, G.W. (1996). Basic fibroblast growth factor and vascular endothelial growth factor are present in epiretinal and choroidal neovascular membranes. Am JOphthalmo/122: 393-403.

FRUTTIGER, M. (2002). Development of the mouse retinal vasculature: angiogenesis versus vasculogenesis. Invest Ophthalmol Vis Sci43: 522-527.

FRUTTIGER, M., CALVER, A.R., KRUGER, W.H., MUDHAR, H.S., MICHALOVICH, D., TAKAKURA, N., NISHIKAWA, S. and RICHARDSON, W.D. (1996). PDGF mediates a neuron-astrocyte interaction in the developing retina. Neuron 17: 11171131.

FUKAI, N., EKLUND, L., MARNEROS, A.G., OH, S.P., KEENE, D.R., TAMARKIN, L., NIEMELA, M., ILVES, M., LI, E., PIHLAJANIEMI, T. and OLSEN, B.R. (2002). Lack of collagen XVIII/endostatin results in eye abnormalities. EMBO J21: 1535-1544.

GALAMBOS, C., NG, Y.S., ALI, A., NOGUCHI, A., LOVEJOY, S., D'AMORE, P.A. and DEMELLO, D.E. (2002). Defective pulmonary development in the absence of heparin-binding vascular endothelial growth factor isoforms. Am J Respir Cell Mol Bio/27: 194-203.

GALE, N.W., THURSTON, G., HACKETT, S.F., RENARD, R., WANG, Q., MCCLAIN J., MARTIN, C., WITTE, C., WITTE, M.H., JACKSON, D., SURI, C., CAMPOCHIARO, P.A., WIEGAND, S.J. and YANCOPOULOS, G.D. (2002). Angiopoietin-2 is required for postnatal angiogenesis and lymphatic patterning, and only the latter role is rescued by Angiopoietin-1. Dev Cel/3: 411-423.

GAO, G., LI, Y., ZHANG, D., GEE, S., CROSSON, C. and MA, J. (2001). Unbalanced expression of VEGF and PEDF in ischemia-induced retinal neovascularization. FEBS Lett 489: 270-276.
GARRETT, K.L., SHEN, W.Y. and RAKOCZY, P.E. (2001). In vivo use of oligonucleotides to inhibit choroidal neovascularisation in the eye. J Gene Med 3: 373-383.

GERBER, H.-P., HILLAN, K.J., RYAN, A.M., KOWALSKI, J., KELLER, G.A. RANGELL, L., WRIGHT, B.D., RADTKE, F., AGUET, M. and FERRARA, N. (1999). VEGF is required for growth and survival in neonatal mice. Development 126: $1149-1159$

GOGAT, K., LE GAT, L., VAN DEN BERGHE, L., MARCHANT, D., KOBETZ, A. GADIN, S., GASSER, B., QUERE, I., ABITBOL, M. and MENASCHE, M. (2004). VEGF and KDR gene expression during human embryonic and fetal eye development. Invest Ophthalmol Vis Sci 45: 7-14

GOLDBERG, M.F. (1997). Persistent fetal vasculature (PFV): an integrated interpretation of signs and symptoms associated with persistent hyperplastic primary vitreous (PHPV). LIV Edward Jackson Memorial Lecture. Am J Ophthalmol124: 587-626

GRANT, M.B., MAY, W.S., CABALLERO, S., BROWN, G.A., GUTHRIE, S.M. MAMES, R.N., BYRNE, B.J., VAUGHT, T., SPOERRI, P.E., PECK, A.B. and SCOTT, E.W. (2002). Adult hematopoietic stem cells provide functional hemangioblast activity during retinal neovascularization. Nat Med8: 607-612.

GREEN, W.R. and ENGER, C. (1993). Age-related macular degeneration histopathologic studies. The 1992 Lorenz E. Zimmerman Lecture. Ophthalmology 100: 1519-1535

HACKETT, S.F., WIEGAND, S., YANCOPOULOS, G. and CAMPOCHIARO, P.A. (2002). Angiopoietin-2 plays an important role in retinal angiogenesis. J Cell Physiol192: 182-187.

HELLSTROM, M., KALEN, M., LINDAHL, P., ABRAMSSON, A. and BETSHOLTZ, C. (1999). Role of PDGF-B and PDGFR- $\beta$ in recruitment of vascular smooth muscle cells and pericytes during embryonic blood vessel formation in the mouse. Development 126: 3047-3055.

HIRSCHI, K., ROHOVSKY, S.A. and D'AMORE, P.A. (1998). PDGF, TGF- $\beta$ and heterotypic cell-cell interactions mediate the recruitment and differentiation of 10T1/2 cells to a smooth muscle cell fate. J Cel/ Bio/141: 805-814.

HIRSCHI, K.K., ROHOVSKY, S.A., BECK, L.H., SMITH, S.R. and D'AMORE, P.A. (1999). Endothelial cells modulate the proliferation of mural cell precursors via platelet-derived growth factor-BB and heterotypic cell contact. Circ. Res. 84: 298-305.

HOLEKAMP, N.M., BOUCK, N. and VOLPERT, O. (2002). Pigment epitheliumderived factor is deficient in the vitreous of patients with choroidal neovascularization due to age-related macular degeneration. Am JOphthalmol 134: $220-227$

HONDA, M., SAKAMOTO, T., ISHIBASHI, T., INOMATA, H. and UENO, H. (2000). Experimental subretinal neovascularization is inhibited by adenovirus-mediated soluble VEGF/flt-1 receptor gene transfection: a role of VEGF and possible treatment for SRN in age-related macular degeneration. Gene Ther7: 978-985.

HOUCK, K.A., LEUNG, D.W., ROWLAND, A.M., WINER, J. and FERRARA, N. (1992). Dual regulation of vascular endothelial growth factor bioavailability by genetic and proteolytic mechanisms. J. Biol. Chem. 257: 26031-26037.

HUGHES, S., YANG, H. and CHAN-LING, T. (2000). Vascularization of the human fetal retina: roles of vasculogenesis and angiogenesis. Invest Ophthalmol Vis Sci41: 1217-1228.

HUTCHINGS, H., MAITRE-BOUBE, M., TOMBRAN-TINK, J. and PLOUET, J. (2002). Pigment epithelium-derived factor exerts opposite effects on endothelia cells of different phenotypes. Biochem Biophys Res Commun 294: 764-769.

ISHIBASHI, T., HATA, Y., YOSHIKAWA, H., NAKAGAWA, K., SUEISHI, K. and INOMATA, H. (1997). Expression of vascular endothelial growth factor in experimental choroidal neovascularization. Graefes Arch Clin Exp Ophthalmol 235: 159-167

ITO, M. and YOSHIOKA, M. (1999). Regression of the hyaloid vessels and pupillary membrane of the mouse. Anat Embryo/200: 403-411.

JANZER, R.C. and RAFF, M.C. (1987). Astrocytes induce blood-brain barrier properties in endothelial cells. Nature 325: 253-257.

KATO, M., PATEL, M.S., LEVASSEUR, R., LOBOV, I., CHANG, B.H., GLASS, D.A., 2ND, HARTMANN, C., LI, L., HWANG, T.H., BRAYTON, C.F., LANG R.A., KARSENTY, G. and CHAN, L. (2002). Cbfa1-independent decrease in osteoblast proliferation, osteopenia, and persistent embryonic eye vascularization in mice deficient in Lrp5, a Wnt coreceptor. J Cell Bio/157: 303-314. 
KEYT, B.A., BERLEAU, L.T., NGUYEN, H.V., CHEN, H., HEINSOHN, H., VANDLEN, R. and FERRARA, N. (1996). The carboxyl-terminal domain (111-165) of vascular endothelial growth factor is critical for its mitogenic potency. J. Biol. Chem. 271: 7788-7795.

KLIFFEN, M., SHARMA, H.S., MOOY, C.M., KERKVLIET, S. and DE JONG, P.T. (1997). Increased expression of angiogenic growth factors in age-related maculopathy. Br J Ophthalmo/81: 154-162.

KORTE, G.E., REPPUCCI, V. and HENKIND, P. (1984). RPE destruction causes choriocapillary atrophy. Invest Ophthalmol Vis Sci25: 1135-1145.

KRZYSTOLIK, M.G., AFSHARI, M.A., ADAMIS, A.P., GAUDREAULT, J., GRAGOUDAS, E.S., MICHAUD, N.A., LI, W., CONNOLLY, E., O'NEILL, C.A. and MILLER, J.W. (2002). Prevention of experimental choroidal neovascularization with intravitreal anti-vascular endothelial growth factor antibody fragment. Arch Ophthalmo/120: 338-346.

KVANTA, A., ALGVERE, P.V., BERGLIN, L. and SEREGARD, S. (1996). Subfoveal fibrovascular membranes in age-related macular degeneration express vascular endothelial growth factor. Invest Ophthalmol Vis Sci37: 1929-1934.

LANG, R., LUSTIG, M., FRANCOIS, F., SELLINGER, M. and PLESKEN, H. (1994). Apoptosis during macrophase-dependent ocular tissue remodelling. Development 120: 3395-3403.

LANG, R.A. and BISHOP, J.M. (1993). Macrophages are required for cell death and tissue remodeling in the developing mouse eye. Cel/74: 453-462.

LEONARD, D.S., SUGINO, I.K., ZHANG, X.G., NINOMIYA, Y., YAGI, F., TSUKAHARA, I., CASTELLARIN, A. and ZARBIN, M.A. (2003). Ultrastructural analysis of hydraulic and abrasive retinal pigment epithelial cell debridements. Exp Eye Res 76: 473-491.

LEUNG, D.W., CACHIANES, G., KUANG, W.-J., GOEDDEL, D.V. and FERRARA, N. (1989). Vascular endothelial growth factor is a secreted angiogenic mitogen. Science 246: 1306-1309.

LINDAHL, P., JOHANSSON, B.R., LEVEEN, P. and BETSHOLTZ, C. (1997). Pericyte loss and microaneurysm formation in PDGF-B-deficient mice. Science 277: 242245.

LOPEZ, P.F., SIPPY, B.D., LAMBERT, H.M., THACH, A.B. and HINTON, D.R. (1996). Transdifferentiated retinal pigment epithelial cells are immunoreactive for vascular endothelial growth factor in surgically excised age-related macular degenerationrelated choroidal neovascular membranes. Invest Ophthalmol Vis Sci37: 855868.

LORENZI, M. and GERHARDINGER, C. (2001). Early cellular and molecular changes induced by diabetes in the retina. Diabetologia 44: 791-804.

MAISONPIERRE, P.C., SURI, C., JONES, P.F., BARTUNKOVA, S., WIEGAND, S.J., RADZIEJEWSKI, C., COMPTON, D., MCCLAIN, J., ALDRICH, T.H., PAPADOPOULOS, N., DALY, T.J., DAVIS, S., SATO, T.N. and YANCOPOULOS, G.D. (1997). Angiopoietin-2, a natural anatognist for Tie2 that disrupts in vivo angiogenesis. Science 277: 55-60.

MALECAZE, F., CLAMENS, S., SIMORRE-PINATEL, V., MATHIS, A., CHOLLET, P., FAVARD, P., BAYARD, F. and PLOUET, J. (1994). Detection of vascular endothelial growth factor messenger RNA and vascular endothelial growth factorlike activity in proliferative diabetic retinopathy. Lab. Sci. 112: 1476-1482.

MAXWELL, P.H. and RATCLIFFE, P.J. (2002). Oxygen sensors and angiogenesis. Semin Cell Dev Biol13: 29-37.

MCKELLER, R.N., FOWLER, J.L., CUNNINGHAM, J.J., WARNER, N., SMEYNE, R.J., ZINDY, F. and SKAPEK, S.X. (2002). The Arf tumor suppressor gene promotes hyaloid vascular regression during mouse eye development. Proc Nat/ Acad Sci USA 99: 3848-3853.

MCLEOD, D.S., LUTTY, G.A., WAJER, S.D. and FLOWER, R.W. (1987). Visualization of a developing vasculature. Microvasc Res 33: 257-269.

MCLEOD, D.S., TAOMOTO, M., OTSUJI, T., GREEN, W.R., SUNNESS, J.S. and LUTTY, G.A. (2002). Quantifying changes in RPE and choroidal vasculature in eyes with age-related macular degeneration. Invest Ophthalmol Vis Sci43: 19861993.

MEESON, A., PALMER, M., CALFON, M. and LANG, R. (1996). A relationship between apoptosis and flow during programmed capillary regression is revealed by vital analysis. Development 122: 3929-3938.

MEESON, A.P., ARGILLA, M., KO, K., WITTE, L. and LANG, R.A. (1999). VEGF deprivation-induced apoptosis is a component of programmed capillary regression. Development 126: 1407-1415.
MICHAELSON, I.C., HERZ, N., LEWKOWITZ, E. and KERTESZ, D. (1954). Effect of increased oxygen on the development of the retinal vessels. Brit. J. Ophthal. 38: 577-587.

MILLER, H., MILLER, B. and RYAN, S.J. (1986). The role of retinal pigment epithelium in the involution of subretinal neovascularization. Invest Ophthalmol Vis Sci 27: 1644-1652.

MILLER, J.W., ADAMIS, A.P., SHIMA, D.T., D'AMORE, P.A., MOULTON, R.S., O'REILLY, M.S., FOLKMAN, J., DVORAK, H.F., BROWN, L.F., BERSE, B., YEO T.-K. and YEO, K.-T. (1994). Vascular permeability factor/vascular endothelial cell growth factor is temporally and spatially correlated with ocular angiogenesis in a primate model. Am. J. Pathol. 145: 574-584.

MITCHELL, C.A., RISAU, W. and DREXLER, H.C. (1998). Regression of vessels in the tunica vasculosa lentis is initiated by coordinated endothelial apoptosis: a role for vascular endothelial growth factor as a survival factor for endothelium. Dev Dyn 213: 322-333.

MOORE, D.J., HUSSAIN, A.A. and MARSHALL, J. (1995). Age-related variation in the hydraulic conductivity of Bruch's membrane. Invest Ophthalmol Vis Sci36: 1290 1297.

NAKAMURA, H. (1988). Electron microscopic study of the prenatal development of the thoracic aorta in the rat. Am. J. Anat. 181: 406-418.

NG, Y.-S., ROHAN, R., SUNDAY, M., DEMELLO, D.E. and D'AMORE, P.A. (2001). Differential expression of VEGF isoforms in mouse during development and in the adult. Dev Dyn220: 112-121.

NODEN, D.M. (1989). Embryonic origins and assembly of blood vessels. Am. Rev. Respir. Dis. 140: 1097-1103.

OGATA, N., MATSUSHIMA, M., TAKADA, Y., TOBE, T., TAKAHASHI, K., YI, X., YAMAMOTO, C., YAMADA, H. and UYAMA, M. (1996). Expression of basic fibroblast growth factor mRNA in developing choroidal neovascularization. Curr Eye Res 15: 1008-1018.

OGATA, N., WADA, M., OTSUJI, T., JO, N., TOMBRAN-TINK, J. and MATSUMURA, M. (2002). Expression of pigment epithelium-derived factor in normal adult rat eye and experimental choroidal neovascularization. Invest Ophthalmol Vis Sci 43: 1168-1175.

OTANI, A., KINDER, K., EWALT, K., OTERO, F.J., SCHIMMEL, P. and FRIEDLANDER, M. (2002). Bone marrow-derived stem cells target retinal astrocytes and can promote or inhibit retinal angiogenesis. Nat Med 8: 1004-1010.

OZAKI, H., HAYASHI, H., VINORES, S.A., MOROMIZATO, Y., CAMPOCHIARO, P and OSHIMA, K. (1997). Intravitreal sustained release of VEGF causes retinal neovascularization in rabbits and breakdown of the blood-retinal barrier in rabbits and primates. Exp Eye Res 4: 505-517.

PARDANAUD, L., YASSINE, F. and DIETERLEN-LIEVRE, F. (1989). Relationship between vasculogenesis, angiogenesis and haemopoiesis during avian ontogeny. Development 105: 473-485.

PEROU, C., JEFFREY, S., VAN DE RUN, M., REES, C., EISEN, M., ROSS, D. PERGAMENSCHIKOV, A., WILLIAMS, C., ZHU, S., LEE, J., D, L., SHALON, D., BROWN, P. and BOTSTEIN, D. (1999). Distinctive gene expression patterns in human mammary epithelial cells and breast cancers. Proc Nat/Acad Sci USA96: 9212-9217.

PIERCE, E.A., AVERY, R.L., FOLEY, E.D., AIELLO, L.P. and SMITH, L.E.H. (1995) Vascular endothelial growth factor/vascular permeability factor expression in a mouse model of retinal neovascularization. Proc. Natl. Acad. Sci. USA92: 905-909.

PROVIS, J.M., LEECH, J., DIAZ, C.M., PENFOLD, P.L., STONE, J. and KESHET, E. (1997). Development of the human retinal vasculature: cellular relations and VEGF expression. Exp Eye Res 65: 555-568.

PROVIS, J.M., SANDERCOE, T. and HENDRICKSON, A.E. (2000). Astrocytes and blood vessels define the foveal rim during primate retinal development. Invest Ophthalmol Vis Sci41: 2827-2836.

RAFII, S. and LYDEN, D. (2003). Therapeutic stem and progenitor cell transplantation for organ vascularization and regeneration. Nat Med9: 702-712.

RAFII, S., MEEUS, S., DIAS, S., HATTORI, K., HEISSIG, B., SHMELKOV, S., RAFII D. and LYDEN, D. (2002). Contribution of marrow-derived progenitors to vascular and cardiac regeneration. Semin Cell Dev Biol13: 61-67.

RAMRATTAN, R.S., VAN DER SCHAFT, T.L., MOOY, C.M., DE BRUIJN, W.C., MULDER, P.G. and DE JONG, P.T. (1994). Morphometric analysis of Bruch's membrane, the choriocapillaris, and the choroid in aging. Invest Ophthalmol Vis Sci35: $2857-2864$ 
RENNO, R.Z., YOUSSRI, A.I., MICHAUD, N., GRAGOUDAS, E.S. and MILLER, J.W. (2002). Expression of pigment epithelium-derived factor in experimental choroidal neovascularization. Invest Ophthalmol Vis Sci43: 1574-1580.

ROBERTS, W.G. and PALADE, G.E. (1995). Increased microvascular permeability and endothelial fenestration induced by vascular endothelial growth factor. J. Cell Sci. 108: 2369-2379.

ROUSSEAU, B., LARRIEU-LAHARGUE, F., BIKFALVI, A. and JAVERZAT, S. (2003). Involvement of fibroblast growth factors in choroidal angiogenesis and retinal vascularization. Exp Eye Res 77: 147-156.

SAKAMOTO, T., SAKAMOTO, H., MURPHY, T.L., SPEE, C., SORIANO, D., ISHIBASHI, T., HINTON, D.R. and RYAN, S.J. (1995). Vessel formation by choroidal endothelial cells in vitro is modulated by retinal pigment epithelial cells. Arch Ophthalmo/113: 512-520.

SARKS, J.P., SARKS, S.H. and KILLINGSWORTH, M.C. (1988). Evolution of geographic atrophy of the retinal pigment epithelium. Eye 2 (Pt 5): 552-577.

SARKS, S.H. (1976). Ageing and degeneration in the macular region: a clinicopathological study. Br J Ophthalmo/60: 324-341.

SCHWESINGER, C., YEE, C., ROHAN, R.M., JOUSSEN, A.M., FERNANDEZ, A., MEYER, T.N., POULAKI, V., MA, J.J., REDMOND, T.M., LIU, S., ADAMIS, A.P. and D'AMATO, R.J. (2001). Intrachoroidal neovascularization in transgenic mice overexpressing vascular endothelial growth factor in the retinal pigment epithelium. Am. J. Pathol. 158: 1161-1172.

SELLHEYER, K. and SPITZNAS, M. (1987). Ultrastructure of the human posterior tunica vasculosa lentis during early gestation. Graefes Arch Clin Exp Ophthalmol 225: 377-383.

SENGER, D.R., GALLI, S.J., DVORAK, A.M., PERUZZI, C.A., HARVEY, V.S. and DVORAK, H.F. (1983). Tumor cells secrete a vascular permeability factor that promotes accumulation of ascites fluid. Science 219: 983-985.

SHEN, W.Y., YU, M.J., BARRY, C.J., CONSTABLE, I.J. and RAKOCZY, P.E. (1998). Expression of cell adhesion molecules and vascular endothelial growth factor in experimental choroidal neovascularisation in the rat. Br J Ophthalmo/82: 10631071.

SHIMA, D.T., GOUGOS, A., MILLER, J.W., TOLENTINO, M., ROBINSON, G., ADAMIS, A.P. and D'AMORE, P.A. (1996). Cloning and mRNA expression of vascular endothelial growth factor in ischemic retinas of Macaca fasicularis. Invest. Ophthalmol. Vis. Sci. 37: 1334-1347.

SHIMA, D.T., KUROKI, M., DEUTSCH, U., NG, Y.-S., ADAMIS, A.P. and D'AMORE, P.A. (1996). The mouse gene for vascular endothelial growth factor. Genomic structure, definition of the transcriptional unit and characterization of transcriptional and post-transcriptional regulatory sequences. J. Biol. Chem. 271: 3877-3883.

SHUI, Y.B., WANG, X., HU, J.S., WANG, S.P., GARCIA, C.M., POTTS, J.D., SHARMA, Y. and BEEBE, D.C. (2003). Vascular endothelial growth factor expression and signaling in the lens. Invest Ophthalmo/ Vis Sci44: 3911-3919.

SMITH, L.E.H., WESLOWSKI, E., MCLELLAN, A., KOSTYK, S.K., D'AMATO, R., SULLIVAN, R. and D'AMORE, P.A. (1994). Oxygen-induced retinopathy in the mouse. Invest. Ophthalmol. Vis. Sci. 35: 101-111.

SOKER, S., FIDDER, H., NEUFELD, G. and KLAGSBRUN, M. (1996). Characterization of novel vascular endothelial growth factor (VEGF) receptors on tumor cells that bind VEGF165 via its exon 7-encoded domain. J. Biol. Chem. 271: 5761-5767.

SPILSBURY, K., GARRETT, K.L., SHEN, W.Y., CONSTABLE, I.J. and RAKOCZY, P.E. (2000). Overexpression of vascular endothelial growth factor (VEGF) in the retinal pigment epithelium leads to the development of choroidal neovascularization. Am. J. Pathol. 157: 135-144.

STALMANS, I., NG, Y.S., ROHAN, R., FRUTTIGER, M., BOUCHE, A., YUCE, A., FUJISAWA, H., HERMANS, B., SHANI, M., JANSEN, S., HICKLIN, D., ANDERSON, D.J., GARDINER, T., HAMMES, H.P., MOONS, L., DEWERCHIN,
M., COLLEN, D., CARMELIET, P. and D'AMORE, P.A. (2002). Arteriolar and venular patterning in retinas of mice selectively expressing VEGF isoforms. JClin Invest 109: 327-336.

STONE, J., CHAN-LING, T., J., P.E., ITIN, A., GNESSIN, H. and KESHET, E. (1996) Roles of vascular endothelial growth factor and astrocyte degeneration in the genesis of retinopathy of prematurity. Invest. Ophthal. Vis. Sci. 37: 290-299.

STONE, J., ITIN, A., ALON, T., PE'ER, J., GNESSIN, H., CHAN-LING, T. and KESHET, E. (1995). Development of retinal vasculature is mediated by hypoxiainduced vascular endothelial growth factor (VEGF) expression by neuroglia. J. Neurosci. 15: 4738-4747.

SURI, C., JONES, P.F., PATAN, S., BARTUNKOVA, S., MAISONPIERRE, P.C., DAVIS, S., SATO, T.N. and YANCOPOULOS, G.D. (1996). Requisite role of angiopoietin-1, a ligand for the TIE2 receptor, during embryonic angiogenesis. Cel/87: 1171-1180.

TAKAHASHI, T., NAKAMURA, T., HAYASHI, A., KAMEI, M., NAKABAYASHI, M. OKADA, A.A., TOMITA, N., KANEDA, Y. and TANO, Y. (2000). Inhibition of experimental choroidal neovascularization by overexpression of tissue inhibitor of metalloproteinases-3 in retinal pigment epithelium cells. Am J Ophtha/mo/130: 774-781.

TISCHER, E., MITCHELL, R., HARTMAN, T., SILVA, M., GOSPODAROWICZ, D., FIDDES, J.C. and ABRAHAM, J.A. (1991). The human gene for vascular endothelial growth factor. Multiple proteins are encoded through alternative exon splicing. J. Biol. Chem. 266: 11947-11954.

TOBE, T., ORTEGA, S., LUNA, J.D., OZAKI, H., OKAMOTO, N., DEREVJANIK, N.L., VINORES, S.A., BASILICO, C. and CAMPOCHIARO, P.A. (1998). Targeted disruption of the FGF2 gene does not prevent choroidal neovascularization in a murine model. Am. J. Pathol. 153: 1641-1646.

TORCZYNSKI, E. (1982). Choroid and suprachoroid. Ocular anatomy, embryology and teratology. FA, J. Philadelphia, Harper \& Row: 553-585.

TOUT, S., CHAN-LING, T., HOLLANDER, H. and STONE, J. (1993). The role of Muller cells in the formation of the blood-retinal barrier. Neuroscience 55: 291-301.

VIRDI, P.S. and HAYREH, S.S. (1982). Ocular neovascularization with retinal vascular occlusion I. Association with experimental retinal vein occlusion. Arch. Ophthalmol. 100: 331-341.

WANG, F., RENDAHL, K.G., MANNING, W.C., QUIROZ, D., COYNE, M. and MILLER, S.S. (2003). AAV-mediated expression of vascular endothelial growth factor induces choroidal neovascularization in rat. Invest Ophthalmol Vis Sci44: 781-790.

XU, Q., WANG, Y., DABDOUB, A., SMALLWOOD, P.M., WILLIAMS, J., WOODS, C., KELLEY, M.W., JIANG, L., TASMAN, W., ZHANG, K. and NATHANS, J. (2004). Vascular development in the retina and inner ear: control by Norrin and Frizzled4, a high-affinity ligand-receptor pair. Ce//116: 883-895.

YAMADA, H., YAMADA, E., KWAK, N., ANDO, A., SUZUKI, A., ESUMI, N., ZACK D.J. and CAMPOCHIARO, P.A. (2000). Cell injury unmasks a latent proangiogenic phenotype in mice with increased expression of FGF2 in the retina. J Cell Physiol 185: $135-142$

YI, X., MAI, L.C., UYAMA, M. and YEW, D.T. (1998). Time-course expression of vascular endothelial growth factor as related to the development of the retinochoroidal vasculature in rats. Exp Brain Res 118: 155-160.

YOUNG, R.W. (1987). Pathophysiology of age-related macular degeneration. Surv Ophthalmo/31: 291-306.

ZHAO, S. and OVERBEEK, P.A. (2001). Regulation of choroid development by the retinal pigment epithelium. Mol Vis 7: 277-282.

ZHU, W.H., GUO, X., VILLASCHI, S. and FRANCESCO NICOSIA, R. (2000). Regulation of vascular growth and regression by matrix metalloproteinases in the rat aorta model of angiogenesis. Laboratory Investigation 80: 545-555. 